\title{
Soil-Corrosion Studies, 1946 and 1948: Copper Alloys, Lead, and Zinc
}

\author{
By Irving A. Denison and Melvin Romanoff
}

\begin{abstract}
This report contains the results of measurements of the corrosion of copper, lead and zinc, and certain alloys of these metals after exposure to different soil conditions for a maximum of 14 years. The soils to which the materials were exposed range from well-aerated soils deficient in soluble salts to very poorly aerated soils containing high concentrations of water-soluble materials. The magnitude and progress of corrosion with respect to weight loss and pitting are interpreted in relation to the composition of the materials and the properties of the soils at the test sites. Comparative data are given for the corrosion of plain iron and steel, copper, lead, and zinc in typical soil environments.
\end{abstract}

\section{Introduction}

The results of the first series of soil corrosion field tests conducted by this Bureau indicated that underground structures of cast iron, wrought iron, and steel could not be expected to withstand for long periods the corrosive action of many of the soils of the United States. Although certain types of installations, such as large-diameter pipe lines, can be protected from corrosion by bituminous coatings supplemented where necessary by cathodic protection, corrosion of certain other underground installations, such as distribution systems of small-diameter pipe, is more readily combatted by metals and alloys that are inherently resistant to corrosion. In order to obtain information on the corrosion resistance of materials otherwise suitable for underground construction, specimens of a variety of metals and alloys were installed at 14 test sites in 1932 .

Sufficient specimens were buried to provide for removal of two specimens of each material after each of five periods of exposure. Accordingly, specimens were removed in 1934, 1937, 1939, 1941, and 1946, and returned to the laboratory for measurement of weight loss and maximum depth of pits. At the time of the removals in 1937 and in 1941, specimens of several alloys of lead and of zinc, and in 1939, specimens of arsenical brass, were buried at the same sites and at one additional site. Specimens of the latter materials were removed from each site at the subsequent removal dates and also in 1948. In this paper results are reported for exposures up to $14 \mathrm{yr}$ for specimens of copper and copper alloys, for exposures up to 11 yr for specimens of lead and zinc, and for exposures up to $9 \mathrm{yr}$ for specimens of arsenical brass. Corrosion data for the removals prior to 1946 have been published in a series of reports that were summarized by K. H. Logan $[1],{ }^{1}$ by whom this investigation was initiated.

The results of corrosion tests of ferrous materials were described in the first report of this series [2]. Succeeding reports will deal with specimens of asbestos-cement, and those with metallic and nonmetallic protective coatings.

\section{Properties of the Soils at the Test Sites}

The test sites were selected not only to represent a wide range of corrosiveness, but also wide differences in the physical and chemical properties of soils. For example, the hydrogen-ion concentration of the soils ranges (table 1) from $\mathrm{pH} 2.6$ to 9.4 , and the resistivity from 62 to $17,800 \mathrm{ohm}$ $\mathrm{cm}$. Differences in the composition of the water soluble material of the soils are also indicated in table 1. The salts contained in soil 64, Docas clay, for example, are seen to consist of sodium and

\footnotetext{
${ }_{1}^{1}$ Figures in brackets indicate the literature reference at the end of this paper
} 
TABLE 1. Properties of the soils at the test sites

\begin{tabular}{|c|c|c|c|c|c|c|c|c|c|c|c|c|c|c|c|c|}
\hline \multicolumn{2}{|r|}{ Soil } & \multirow{2}{*}{ Location } & \multirow{2}{*}{$\begin{array}{l}\text { Aera- } \\
\text { tion }\end{array}$} & \multirow{2}{*}{$\begin{array}{l}\text { Mois- } \\
\text { ture } \\
\text { equiv- } \\
\text { alent }\end{array}$} & \multirow{2}{*}{$\begin{array}{l}\text { Ap- } \\
\text { par- } \\
\text { ent } \\
\text { spe- } \\
\text { cific } \\
\text { grav- } \\
\text { ity }\end{array}$} & \multirow{2}{*}{$\begin{array}{c}\text { Resis- } \\
\text { tivity } \\
\text { at } \\
60^{\circ} \mathrm{F} \\
\left(15.6^{\circ}\right. \\
\mathrm{C})\end{array}$} & \multirow{2}{*}{$\mathrm{pH}$} & \multirow{2}{*}{$\begin{array}{c}\text { Total } \\
\text { acidity } \\
\text { (milli- } \\
\text { gram } \\
\text { equiv- } \\
\text { alents } \\
\text { per } \\
100 \mathrm{~g} \\
\text { of soil) }\end{array}$} & \multirow{2}{*}{$\begin{array}{c}\text { Sul- } \\
\text { fide } \\
\text { con- } \\
\text { tent }\end{array}$} & \multicolumn{7}{|c|}{$\begin{array}{c}\text { Composition of water extract-milligram equivalents } \\
\text { per } 100 \mathrm{~g} \text { of soil }\end{array}$} \\
\hline No. & Type & & & & & & & & & $\begin{array}{c}\mathrm{Na}+\mathrm{K} \\
\text { as } \mathrm{Na}\end{array}$ & $\mathrm{Ca}$ & $\mathrm{Mg}$ & $\mathrm{CO}_{3}$ & $\mathrm{HCO}_{3}$ & $\mathrm{Cl}$ & $\mathrm{SO}_{4}$ \\
\hline 51 & Acadia clay ... & Spindletop, Tex_-. & $\mathrm{P}$ & $\begin{array}{c}\text { Per- } \\
\text { cent } \\
47.1\end{array}$ & 2.07 & $\begin{array}{c}\mathrm{Ohm}- \\
\mathrm{cm} \\
190\end{array}$ & 6.2 & 13. 2 & + & 10.27 & 15.55 & 5.03 & 0.00 & 0.56 & 5.75 & 22.00 \\
\hline 53 & Cecil clay loam ...... & Atlanta, Ga & G & 33.7 & 1. 60 & 17,800 & 4.8 & 5.1 & - & F & - & $\ldots$ & & & & \\
\hline 55 & Hagerstown loam . & Loch Raven, Md & G & 32.0 & 1.49 & 5,210 & 5.8 & 10.9 & - & & & & & & & \\
\hline 56 & Lake Charles clay.. & El Vista, Tex ..... & VP & 28.7 & 2. 03 & 406 & 7.1 & 5. 1 & + & 3.12 & 0.69 & 0.47 & .00 & .80 & 1. 59 & 3. 04 \\
\hline 58 & Muck ...... & New Orleans, $\mathrm{La}_{\ldots}$ & $\mathrm{P}$ & 57.8 & 1. 43 & 712 & 4.8 & 15.0 & ++ & 2. 03 & 2. 23 & 1. 29 & .00 & .00 & 0.47 & 2. 54 \\
\hline 59 & Carlisle muck.. & Kalamazoo, Mich.. & VP & 43.6 & & 1,660 & 5.6 & 12.6 & +++ & 1.03 & 3.08 & 2. 70 & .00 & .00 & 3.47 & 1.04 \\
\hline 60 & Rifle peat.......... & Piymouth, Ohio & $\mathrm{P}$ & 43.4 & 1. 28 & 218 & 2.6 & 297.4 & +++ & 2. 91 & 10.95 & 2.86 & .00 & .00 & 0.00 & 56.70 \\
\hline 61 & Sharkey clay....... & New Orleans, La_-- & $\mathrm{P}$ & 30.8 & 1.78 & 943 & 6.8 & 4.9 & + & 0.73 & 0.68 & 0.33 & .00 & .71 & .10 & 0.91 \\
\hline 62 & Susquehanna clay & Meridian, Miss .... & $\mathrm{F}$ & 34.6 & 1. 79 & 6,920 & 4.5 & 12.0 & - & & & & & & & \\
\hline 63 & Tidal marsh & Charleston, S. C... & VP & 46.7 & 1.47 & 84 & 6.9 & 14.6 & +++ & 33.60 & 6.85 & 4. 00 & .00 & .00 & 12.70 & 36.60 \\
\hline 64 & Docas clay & Cholame, Calif..... & $\mathrm{P}$ & 41.1 & 1.88 & 62 & 7.5 & A & - & 28.10 & 2. 29 & 0.76 & .00 & .89 & 28.80 & 0.26 \\
\hline 65 & Chino silt loam & Wilmington, Calif & G & 26.4 & 1.41 & 148 & 8.0 & A & - & 7.65 & 12. 40 & 2. 20 & .00 & 1. 30 & 6.05 & 16. 90 \\
\hline 66 & $\begin{array}{l}\text { Mohave fine grav- } \\
\text { elly loam. }\end{array}$ & Phoenix, Ariz & $\mathrm{F}$ & 16.5 & 1.79 & 232 & 8.0 & A & - & 6.55 & 0.51 & 0.18 & .00 & 0.73 & 2. 77 & 2. 97 \\
\hline 67 & Cinders & Milwaukee, Wis . . & VP & & & 455 & 7.6 & A & ++ & 0.77 & 3.03 & .53 & .00 & .55 & 0.08 & 2. 89 \\
\hline 70 & Merced silt loam ... & Buttonwillow Calif_ & $\mathrm{F}$ & 24.7 & 1.69 & 278 & 9.4 & A & - & 8.38 & 0.38 & .22 & .02 & 1.87 & 1.12 & 5. 57 \\
\hline
\end{tabular}

- Aeration of soils: G, good; F, fair; P, poor; VP, very poor.

b A indicates absence of acidity because of alkaline reaction.

-- , Sulfides absent; + , sulfides present in low concentration; ++ , sulfides present in moderate concentration; +++ , sulfides present in high concentration

potassium chlorides; whereas, the salts in soil 60 , Rifle peat, are sulfates of the alkalies and of the alkaline earth metals.

The retentiveness of the soils for moisture is indicated by values for the moisture equivalent, i. e., the quantity of water retained by a previously saturated soil subjected to a centrifugal force of 1,000 times the force of gravity.

Values for apparent specific gravity are presented as relative measures of the porosity of the soils. Because the real specific gravity of the mineral portion of soils varies within narrow limits, the apparent specific gravity indicates the compactness and, hence, porosity of soils that are primarily inorganic in nature.

\section{Description of the Materials}

The form, dimensions, and composition of the specimens of copper and copper alloys are given in table 2. Specimens of some materials were in the form of pipe, others of plate. The ends of the pipe specimens were closed by caps to exclude moisture, thereby preventing corrosion of the interior. An additional precaution was taken to prevent internal corrosion by coating the internal surface of the pipe specimens with a heavy grease. The exposed area of most of the specimens was approximately $0.3 \mathrm{ft}^{2}{ }^{2}$ Microphotographs of the copper and copper alloys studied are shown in figures 1 and 2 .

The compositions of the zinc and lead specimens are given in table 3 . The composition of material $\mathrm{Z}$ corresponds approximately to that of "highgrade" zinc slab. The die-casting zine alloy CZ is substantially the same as ASTM alloy XXV. The lead alloys contained copper, antimony, tellurium, or tin in various amounts to produce greater hardness and better mechanical properties than ordinary lead. 
TABLE 2. Composition of copper and copper alloys

\begin{tabular}{|c|c|c|c|c|c|c|c|c|c|c|c|c|c|c|c|c|c|}
\hline Material & $\begin{array}{l}\text { Identi- } \\
\text { fica- } \\
\text { tion }\end{array}$ & $\begin{array}{c}\text { Year } \\
\text { buried }\end{array}$ & Form & $\begin{array}{c}\text { Ex- } \\
\text { ternal } \\
\text { width } \\
\text { or di- } \\
\text { ameter }\end{array}$ & Length & $\begin{array}{l}\text { Wall } \\
\text { thick- } \\
\text { ness }\end{array}$ & $\begin{array}{l}\text { Den- } \\
\text { sity }\end{array}$ & $\mathrm{Cu}$ & $\mathrm{Zn}$ & Sn & $\mathrm{Pb}$ & $\mathrm{Ni}$ & $\mathrm{Fe}$ & $\mathrm{Si}$ & $\mathrm{Mn}$ & $\mathrm{P}$ & As \\
\hline & & & & in. & in. & in. & $l b . / f t .^{3}$ & $\%$ & $\%$ & $\%$ & $\%$ & $\%$ & $\%$ & $\%$ & $\%$ & $\%$ & $\%$ \\
\hline $\begin{array}{l}\text { Tough-pitch copper } \\
\text { Deoxidized copper }\end{array}$ & $\begin{array}{l}C \\
A\end{array}$ & $\begin{array}{l}1932 \\
1932\end{array}$ & $\begin{array}{c}\text { Pipe ..... } \\
\text { do }\end{array}$ & 1.7 & 12 & 0.145 & 555 & 99.9 & $\cdots$ & $\cdots$ & $\cdots$ & -... & $\cdots$ & $\cdots$ & -..- & $\cdots$ & $\cdots$ \\
\hline $\begin{array}{l}\text { Deoxidized copper } \\
\text { Copper with soldered fittings }\end{array}$ & $\begin{array}{c}A \\
M\end{array}$ & $\begin{array}{l}1932 \\
1932\end{array}$ & do & $\begin{array}{l}1.7 \\
1.5\end{array}$ & $\begin{array}{l}13 \\
12\end{array}$ & .144 & 558 & 99.94 & -... & $\cdots$ & $\cdots$ & $\cdots$ & -..- & -..- & -..- & 0.18 & ... \\
\hline Red brass & $\begin{array}{c}M \\
F\end{array}$ & $\begin{array}{l}1932 \\
1932\end{array}$ & ...... do_. & $\begin{array}{l}1.0 \\
1.7\end{array}$ & $\begin{array}{l}12 \\
12\end{array}$ & $\begin{array}{r}.062 \\
.143\end{array}$ & $\begin{array}{c}\cdots- \\
546\end{array}$ & 85.18 & 14.80 & $\cdots$ & $\cdots$ & $\ldots$ & 0.01 & $\cdots$ & $\cdots$ & $\cdots$ & $\cdots$ \\
\hline Admiralty metal & $H$ & 1932 & _..... do & 1.7 & 12 & .143 & 532 & 71.28 & 27.39 & 1. 30 & 0.01 & $\cdots$ & .02 & $-\ldots$ & $-\cdots$ & -..- & -... \\
\hline Leaded-silicon brass_. & K & 1932 & ......do_. & 1.7 & 12 & .08 & 532 & 67.08 & 31.07 & $\ldots$ & .84 & .... & Trace & 1.01 & .... & .... & .... \\
\hline Yellow brass ........ & $J$ & 1932 & ...... do_. & 1.7 & 13 & .145 & 529 & 66.50 & 33.06 & .... & 42 & -..- & 0.02 & .... & .... & .... & .... \\
\hline Muntz metal. . & $L$ & 1932 & ......do_. & 1.7 & 12 & .03 & 524 & 60.06 & 39.58 & .... & .36 & -... & Trace & .... & .... & .... & -... \\
\hline Muntz metal with arsenic. & $B$ & 1939 & Plate & 2.5 & 12 & .25 & 524 & 62.37 & 37.54 & .... & .005 & -... & 0.007 & -... & .... & .... & 0.08 \\
\hline Copper-silicon alloy _... & $E$ & 1932 & Pipe $\ldots . .$. & 1.7 & 12 & .141 & 548 & 97.15 & .... & 1.80 & -... & -..- & .01 & 1.04 & .... & -..- & .... \\
\hline Do & $N$ & 1932 & ...... do & 1.7 & 12 & .145 & 546 & 98.11 & .... & 0.14 & .... & 0.01 & .11 & 1.49 & 0.18 & .... & ..... \\
\hline Do $\ldots$ & $D$ & 1932 & ..... do & 1.7 & 12 & .143 & 532 & 95.46 & .... & ....- & .... & .08 & .21 & 3. 19 & 1.06 & -... & .... \\
\hline Copper-nickel-zine alloy & $G$ & 1932 & .....do.. & 1.7 & 12 & .145 & 553 & 74.45 & 4. 99 & .... & -... & 20.04 & -...- & -... & 0.52 & .... & .... \\
\hline
\end{tabular}

Table 3. Composition of zinc and lead alloys

\begin{tabular}{|c|c|c|c|c|c|c|c|c|c|c|c|c|c|c|c|c|c|c|c|}
\hline Material & $\begin{array}{l}\text { Identi- } \\
\text { fication }\end{array}$ & $\begin{array}{c}\text { Year } \\
\text { buried }\end{array}$ & Form & $\begin{array}{l}\text { Nomi- } \\
\text { nal di- } \\
\text { ameter } \\
\text { or } \\
\text { width }\end{array}$ & Length & $\begin{array}{l}\text { Thick- } \\
\text { ness }\end{array}$ & $\begin{array}{l}\text { Densi- } \\
\text { ty }\end{array}$ & $\mathrm{Zn}_{\mathrm{n}}$ & $\mathrm{Al}$ & $\mathrm{Cu}$ & $\mathrm{Fe}$ & $\mathrm{Pb}$ & $\mathrm{Sn}$ & $\mathrm{Bi}$ & $\mathrm{Sb}$ & $\mathrm{Cd}$ & $\mathrm{Te}$ & $\mathrm{Ca}$ & $\mathrm{Mg}$ \\
\hline \multicolumn{20}{|c|}{ ZINC } \\
\hline $\begin{array}{l}\text { Rolled zinc } \\
\text { Die-casting zinc. }\end{array}$ & $\begin{array}{c}\mathrm{Z} \\
\mathrm{CZ}\end{array}$ & $\begin{array}{l}1937 \\
1937\end{array}$ & plate_... & $\begin{array}{l}\text { in. } \\
2.3 \\
4.4\end{array}$ & $\begin{array}{l}\text { in. } \\
12 . \\
6.8\end{array}$ & $\begin{array}{l}\text { in. } \\
0.15 \\
.125\end{array}$ & $\begin{array}{c}l b / f t^{3} \\
449 \\
418\end{array}$ & $\begin{array}{c}\% \\
\text { × } 99.89 \\
\text { × } 94.9\end{array}$ & $\begin{array}{c}\% \\
-.00\end{array}$ & $\begin{array}{c}\% \\
-1.05\end{array}$ & $\begin{array}{c}\% \\
0.009 \\
.018\end{array}$ & $\begin{aligned} & \% \\
&< 0.095 \\
&<.003\end{aligned}$ & $\begin{array}{c}\% \\
<0.001\end{array}$ & $\begin{array}{c}\% \\
\end{array}$ & $\%$ & $\begin{array}{c}\% \\
0.0038 \\
<.003\end{array}$ & $\%$ & $\%$ & $\begin{array}{r}\% \\
0.02 \text { to } \\
.05\end{array}$ \\
\hline \multicolumn{20}{|c|}{ LEAD } \\
\hline Chemical lead & o & 1937 & pipe.. & 1.5 & 12. & 0.177 & 709 & ....... & 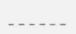 & 0.056 & ....... & a99. 94 & None & 0.002 & 0.0011 & & & .... & $\ldots$ \\
\hline Tellurium lead & $\mathrm{T}$ & 1937 & ... do _. & 1.5 & 12. & .177 & 709 & ....... & -...... & .082 & 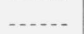 & a99. 87 & None & None & .0011 & -.... & 0.043 & .... & ..... \\
\hline Antimonial lead _. & B & 1937 & ... do ... & 1.5 & 12. & .177 & 687 & ....... & ....... & .036 & ....... & a94. 64 & None & 0.016 & 5. 31 & -...... & ...... & …- & 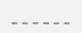 \\
\hline Special lead alloy & b M & 1941 & .... do ... & 1. 25 & 15. & .172 & 709 & -...... & -...... & -..... & -...... & a99.7 & 0.25 & -... & -...... & -..... & .... & 0.02 & 0.02 \\
\hline
\end{tabular}

a By difference.

b This material also contains the usual impurities found in lead, 


\section{Copper and Copper-Silicon Alloys}

\section{Loss in Weight and Depth of Pitting}

Prior to examination, the corroded specimens were cleaned by methods that have been previously described [1]. The extent of corrosion was measured by the loss in weight after exposure and by the depths of the deepest pits. These data are recorded in table 4 . Unless indicated otherwise, each value is the average of measurements made on two specimens. Except as noted in table 4, the exposure periods at the different test sites did not differ by more than 5 percent.
The condition of specimens of tough pitch copper after exposure at 14 test sites for $14 \mathrm{yr}$ is illustrated in figure 3. Because of the shallowness of many of the pits, the appearance of the specimens is somewhat deceptive in giving the impression that copper tends to corrode uniformly. Actually, as will be seen later, copper exposed to soils shows the same general tendency toward localized corrosion as is shown by cast iron, wrought iron, and steel.

The progress of corrosion with time for toughpitch copper $\mathrm{C}$, deoxidized copper $\mathrm{A}$, and coppersilicon alloys $\mathrm{D}, \mathrm{E}$, and $\mathrm{N}$ is shown in figure 4 .

TABLE 4. Loss in weight and depth of maximum penetration of copper and copper-silicon alloys

(Average of two specimens)

\begin{tabular}{|c|c|c|c|c|c|c|c|c|c|c|c|c|c|c|c|c|}
\hline \multirow[b]{3}{*}{$\begin{array}{c}\text { Iden- } \\
\text { tifi- } \\
\text { cation }\end{array}$} & \multirow[b]{3}{*}{ Material } & \multirow{3}{*}{$\begin{array}{l}\text { Aver- } \\
\text { age } \\
\text { expo- } \\
\text { sure }\end{array}$} & \multicolumn{14}{|c|}{ Test site number and soil type } \\
\hline & & & 51 & 53 & 55 & 56 & 58 & 59 & 60 & 61 & 62 & 63 & 64 & 65 & 66 & 67 \\
\hline & & & $\begin{array}{c}\text { A cadia } \\
\text { clay }\end{array}$ & $\begin{array}{l}\text { Cecil } \\
\text { clay } \\
\text { loam }\end{array}$ & $\begin{array}{l}\text { Ha- } \\
\text { gers- } \\
\text { town } \\
\text { loam }\end{array}$ & $\begin{array}{c}\text { Lake } \\
\text { Charles } \\
\text { clay }\end{array}$ & Muck & $\begin{array}{l}\text { Car- } \\
\text { lisle } \\
\text { muck }\end{array}$ & $\begin{array}{l}\text { Rifle } \\
\text { peat }\end{array}$ & $\begin{array}{l}\text { Shar- } \\
\text { key } \\
\text { clay }\end{array}$ & $\begin{array}{c}\text { Sus- } \\
\text { que- } \\
\text { hanna } \\
\text { clay }\end{array}$ & $\begin{array}{l}\text { Tidal } \\
\text { marsh }\end{array}$ & $\begin{array}{l}\text { Docas } \\
\text { clay }\end{array}$ & $\begin{array}{l}\text { Chino } \\
\text { silt } \\
\text { loam }\end{array}$ & $\begin{array}{l}\text { Mo- } \\
\text { have } \\
\text { fine } \\
\text { grav- } \\
\text { elly } \\
\text { loam }\end{array}$ & Cinders \\
\hline
\end{tabular}

LOSS IN WEIGHT (OUNCES PER SQUARE FOOT) ^

\begin{tabular}{|c|c|c|c|c|c|c|c|c|c|c|c|c|c|c|c|c|}
\hline \multirow{5}{*}{ A } & \multirow{5}{*}{ Deoxidized copper.......... } & $\begin{array}{r}\text { Years } \\
2.0\end{array}$ & 0.40 & 0.12 & 0.14 & 0.10 & 0.16 & 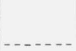 & 1. 47 & b 0.06 & 0.16 & 1. 13 & 1. 41 & 1. 71 & 0.28 & 3.98 \\
\hline & & 5.4 & 1. 01 & .15 & .14 & .51 & 1. 56 & 0.12 & 3.82 & .35 & .26 & 2.45 & 2.22 & c 1.02 & c. 75 & 9.33 \\
\hline & & 7.4 & 0.40 & .20 & .15 & .80 & 1. 72 & c. 11 & 1. 10 & .38 & .38 & 4. 25 & 3.00 & c 2.37 & ${ }^{\circ} 1.32$ & 4. 89 \\
\hline & & 9.3 & -...... & .22 & .18 & .78 & 2.10 & .11 & 5.01 & .35 & .48 & 4. 22 & 5.32 & 0.24 & с 0.62 & 11.50 \\
\hline & & 14.3 & d. 60 & .24 & .16 & .89 & 2.39 & d. 21 & 11. 97 & .66 & .52 & 6.57 & 5.17 & 1.07 & .54 & 13.77 \\
\hline \multirow{5}{*}{$\mathrm{C}$} & \multirow{5}{*}{ Tough-pitch copper....... } & 2.0 & .42 & .12 & e. 14 & .12 & 0.13 & -.... & 1.37 & b. 09 & .15 & 1.31 & 0.67 & 0.50 & .11 & 3.15 \\
\hline & & 5.4 & .91 & .16 & .19 & .34 & 1.40 & .13 & 4. 68 & .34 & .26 & 2. 99 & .96 & .47 & .16 & 8.04 \\
\hline & & 7.4 & .35 & .23 & .17 & 60 & 1. 66 & c. 09 & 1.03 & .37 & .33 & 4.33 & 1. 56 & .55 & .32 & 1. 42 \\
\hline & & 9.3 & -.... & .24 & .20 & .71 & 1.95 & .12 & 7.26 & .33 & .36 & 4. 46 & 2.80 & .26 & .45 & 9.84 \\
\hline & & 14.3 & d. 46 & .23 & .16 & .61 & 1.98 & d. 19 & e 14.66 & .58 & .49 & 8.31 & 1.04 & .47 & .27 & 6.71 \\
\hline \multirow{5}{*}{$\mathrm{N}$} & \multirow{5}{*}{ Copper-silicon alloy } & 2.0 & .35 & .19 & .14 & .16 & 0.11 & $\ldots$ & 1.57 & b. 14 & .25 & 1.45 & 1.32 & 1.03 & .22 & 5.37 \\
\hline & & 5. 4 & 1. 02 & .24 & .28 & .32 & 1. 36 & .22 & 4. 13 & .42 & .40 & 4.37 & 2.10 & 0.53 & c. 67 & 15.51 \\
\hline & & 7.4 & 0.48 & .38 & .23 & .40 & 1. 70 & c. 14 & 1.06 & .38 & .42 & 4.57 & 1. 74 & 2. 42 & .55 & 1. 99 \\
\hline & & 9.3 & - & .30 & .30 & .62 & 1.97 & c. 24 & c 3.96 & .48 & .57 & 6.96 & 4. 87 & 0.62 & c. 51 & 22.51 \\
\hline & & ( 14.3 & .53 & .51 & .38 & .60 & 2.80 & d. 26 & 10.65 & .77 & .54 & 8.30 & 4. 59 & .66 & .53 & 9.46 \\
\hline \multirow{6}{*}{${ }^{f} \mathrm{~N}_{1}$} & \multirow{5}{*}{ Copper-silicon alloy } & 2.0 & & & & .14 & & & 0.79 & b. 12 & .15 & 1. 98 & 1. 48 & 1. 23 & .14 & 5. 90 \\
\hline & & 5.4 & & .21 & & & ... & .26 & & .24 & & & 1.38 & & & \\
\hline & & 7.4 & -..... & .25 & & ....... & 1. 56 & - & ...... & - & ..... & - & . . . & 2. 74 & - . & . \\
\hline & & 9.3 & - & & ... & -... & & - & 1. 82 & 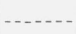 & $\ldots$ & - & 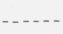 & - & .34 & 23.17 \\
\hline & & 14.3 & -..... & -... & .29 & .55 & (n) & .20 & & $\cdots$ & .44 & 6.84 & - - & & & \\
\hline & \multirow{5}{*}{ Copper-silicon alloy } & 2.0 & .51 & .24 & .29 & .23 & 0.19 & .... & 1. 61 & b. 19 & .33 & 1. 16 & 0.79 & 0.48 & .38 & 3.25 \\
\hline \multirow{4}{*}{$\mathrm{E}$} & & 5.4 & 1. 04 & .28 & .29 & .48 & 1. 64 & .28 & 3.76 & .51 & .61 & 1. 93 & 1. 26 & .72 & .51 & 5. 63 \\
\hline & & 7.4 & 0.97 & .38 & .24 & .60 & 1. 67 & e. 23 & 1. 03 & .65 & .52 & 3.53 & 1.44 & 1.17 & 1. 22 & 1. 47 \\
\hline & & 9.3 & -..... & .37 & .35 & .76 & 2.11 & .17 & с 3.22 & .61 & .69 & c 4.38 & 2.30 & 0.96 & c 1.53 & 8. 76 \\
\hline & & 14.3 & d 1.40 & .45 & .26 & .70 & 2. 73 & d. 31 & 9.32 & .87 & .70 & 4.84 & 2.82 & 1. 42 & 1.82 & 8.49 \\
\hline \multirow{5}{*}{$\mathrm{D}$} & \multirow{5}{*}{ Copper-silicon alloy } & 2.0 & 0.45 & .18 & .15 & .10 & 0.11 & & 1. 33 & b. 13 & .24 & 1. 23 & 0.67 & 1. 10 & 0.21 & 4. 23 \\
\hline & & 5.4 & 1. 07 & .25 & .20 & .35 & 1. 70 & .10 & 3.32 & .52 & .42 & 2. 64 & 1.14 & с 0.62 & c. 53 & 20.95 \\
\hline & & 7. 4 & 0.41 & .39 & .28 & .52 & 1. 75 & c. 18 & 0.72 & .61 & .50 & 4. 86 & 1.43 & c 1.28 & .40 & 2. 69 \\
\hline & & 9.3 & $\ldots$ & .36 & .28 & .63 & 2. 12 & .15 & 4. 46 & .52 & .60 & 5. 32 & 2.88 & 0.48 & .55 & 13.47 \\
\hline & & 14.3 & d. 55 & .48 & .24 & .77 & 2. 49 & d. 21 & 9. 74 & .88 & .66 & 5.16 & 2.81 & 1. 24 & .45 & 17.34 \\
\hline
\end{tabular}

See footnotes at end of table. 
TABLE 4. Loss in weight and depth of maximum penetration of copper and copper-silicon alloys-Continued

(Average of two specimens)

\begin{tabular}{|c|c|c|c|c|c|c|c|c|c|c|c|c|c|c|c|c|}
\hline \multirow{3}{*}{$\begin{array}{c}\text { Iden- } \\
\text { tifi- } \\
\text { cation }\end{array}$} & \multirow{3}{*}{ Material } & \multirow{3}{*}{$\begin{array}{c}\text { A ver- } \\
\text { age } \\
\text { expo- } \\
\text { sure }\end{array}$} & \multicolumn{14}{|c|}{ Test site number and soil type } \\
\hline & & & 51 & 53 & 55 & 56 & 58 & 59 & 60 & 61 & 62 & 63 & 64 & 65 & 66 & 67 \\
\hline & & & $\begin{array}{l}\text { Acadia } \\
\text { clay }\end{array}$ & $\begin{array}{l}\text { Cecil } \\
\text { clay } \\
\text { loam }\end{array}$ & $\begin{array}{l}\text { Ha- } \\
\text { gers- } \\
\text { town } \\
\text { loam }\end{array}$ & $\begin{array}{c}\text { Lake } \\
\text { Charles } \\
\text { clay }\end{array}$ & Muck & $\begin{array}{l}\text { Car- } \\
\text { lisle } \\
\text { muck }\end{array}$ & $\begin{array}{l}\text { Rifle } \\
\text { peat }\end{array}$ & $\begin{array}{l}\text { Shar- } \\
\text { key } \\
\text { clay }\end{array}$ & $\begin{array}{l}\text { Sus- } \\
\text { que- } \\
\text { hanna } \\
\text { clay }\end{array}$ & $\begin{array}{l}\text { Tidal } \\
\text { marsh }\end{array}$ & $\begin{array}{l}\text { Docas } \\
\text { clay }\end{array}$ & $\begin{array}{l}\text { Chino } \\
\text { silt } \\
\text { loam }\end{array}$ & $\begin{array}{l}\text { Mo- } \\
\text { have } \\
\text { fine } \\
\text { grav- } \\
\text { elly } \\
\text { loam }\end{array}$ & Cinders \\
\hline
\end{tabular}

MAXIMUM PENETRATION (MILS)

\begin{tabular}{|c|c|c|c|c|c|c|c|c|c|c|c|c|c|c|c|c|}
\hline \multirow{5}{*}{ A } & \multirow{5}{*}{ Deoxidized copper - } & $\begin{array}{l}\text { Years } \\
\quad 2.0\end{array}$ & g M & $<6$ & $<6$ & M & M & & 7 & $\mathrm{~b}<6$ & $<6$ & M & $<6$ & $<6$ & 6 & 38 \\
\hline & & 5.4 & $<6$ & 7 & $<6$ & $<6$ & 12 & $<6$ & 28 & $\cdot 23$ & 9 & M & 9 & 10 & 7 & 54 \\
\hline & & 7.4 & $<6$ & 10 & $<6$ & $<6$ & 10 & $<6$ & 8 & 8 & 14 & 8 & $<6$ & 18 & 8 & 44 \\
\hline & & 9.3 & & $<6$ & $<6$ & $<6$ & $\circ 14$ & $<6$ & 38 & 8 & 8 & 10 & c 16 & $<6$ & 10 & 88 \\
\hline & & 14.3 & $d<6$ & 8 & $<6$ & $<6$ & 19 & d 6 & 48 & 24 & 10 & 10 & 10 & 9 & 10 & 64 \\
\hline \multirow{5}{*}{$\mathrm{C}$} & \multirow{5}{*}{ Tough-pitch copper } & 2.0 & $\mathrm{M}$ & $\mathrm{M}$ & e $<6$ & $\mathrm{M}$ & $<6$ & & $<6$ & $\mathrm{~b}<6$ & $<6$ & $<6$ & 7 & $<6$ & $<6$ & 26 \\
\hline & & 5.4 & $<6$ & $<6$ & 6 & $<6$ & 12 & 6 & 33 & c 15 & 6 & $<6$ & 8 & 9 & $<6$ & 56 \\
\hline & & 7.4 & $<6$ & 11 & 7 & 8 & 14 & 6 & 9 & 16 & 6 & 7 & 14 & 20 & $<6$ & 24 \\
\hline & & 9.3 & & 6 & 8 & $<6$ & 10 & $<6$ & 40 & 8 & 8 & 6 & c 14 & 10 & $<6$ & 51 \\
\hline & & (14.3 & $\mathrm{d}<6$ & 6 & $<6$ & $<6$ & 16 & d 6 & 46 & 20 & 10 & 14 & 14 & 12 & $<6$ & 42 \\
\hline \multirow{5}{*}{$\mathrm{N}$} & \multirow{5}{*}{ Copper-silicon alloy .. } & 2. 0 & M & $<6$ & $<6$ & $<6$ & M & & 7 & $\mathrm{~b}<6$ & $<6$ & $<6$ & 10 & 6 & 15 & 46 \\
\hline & & 5.4 & $<6$ & 6 & 8 & $<6$ & 7 & $<6$ & 17 & 11 & $<6$ & $<6$ & 10 & 16 & a 18 & 80 \\
\hline & & 7.4 & $<6$ & $<6$ & 6 & $<6$ & 9 & $<6$ & $<6$ & 11 & 6 & 6 & 12 & 20 & 14 & 31 \\
\hline & & 9.3 & & $<6$ & $<6$ & $<6$ & 12 & M & 10 & 10 & $<6$ & 12 & 21 & 20 & 13 & b $145+$ \\
\hline & & 14.3 & $\mathrm{~d}<6$ & 6 & 7 & $<6$ & 15 & $\mathrm{~d}<6$ & 24 & 17 & 6 & 16 & 16 & 12 & 10 & 42 \\
\hline \multirow{5}{*}{${ }^{f} \mathrm{~N}_{1}$} & \multirow{5}{*}{ Copper-silicen alloy } & 2. 0 & & & & $<6$ & & & 7 & $\mathrm{~b}<6$ & $<6$ & $<6$ & 10 & 15 & M & 40 \\
\hline & & 5.4 & & $<6$ & & & & $<6$ & & $<6$ & & & 12 & & & \\
\hline & & 7.4 & & 9 & & & 16 & & -.. & & & & 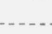 & 24 & & …. \\
\hline & & 9.3 & & & & & & & 8 & & & & & & $<6$ & 90 \\
\hline & & 14.3 & & $\cdots$ & 7 & $<6$ & $\ldots$ & 11 & & 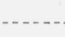 & 8 & 11 & & & & \\
\hline \multirow{5}{*}{$\mathrm{E}$} & \multirow{5}{*}{ Copper-silicon alloy } & 2. 0 & $<6$ & 12 & 13 & 12 & 11 & ... & 24 & $\mathrm{~b}<6$ & 14 & 16 & 20 & 23 & 12 & 38 \\
\hline & & 5.4 & 8 & 14 & 16 & 9 & 33 & 11 & 22 & 26 & 15 & $<6$ & 19 & 21 & 16 & 49 \\
\hline & & 7.4 & 6 & 14 & 15 & 12 & 33 & 6 & 12 & 35 & $<6$ & 14 & 12 & 33 & 15 & 33 \\
\hline & & 9.3 & & 12 & 20 & 12 & 53 & 20 & 18 & - 37 & 22 & 10 & 34 & 22 & 22 & 102 \\
\hline & & 14.3 & d 15 & 20 & 20 & 12 & 54 & d 16 & 35 & 42 & 23 & 11 & 22 & 23 & 21 & 78 \\
\hline \multirow{5}{*}{$\mathrm{D}$} & \multirow{5}{*}{ Copper-silicon alloy .- } & 2. 0 & M & $<6$ & 7 & M & . M & ........ & $<6$ & b $\mathrm{M}$ & 6 & $<6$ & 19 & $<6$ & $<6$ & 34 \\
\hline & & 5.4 & 11 & 10 & 10 & M & 8 & M & 15 & 7 & 10 & $<6$ & 11 & 11 & c 12 & 90 \\
\hline & & 7.4 & $<6$ & $<6$ & $1 Q$ & 7 & 12 & $<6$ & $<6$ & 6 & 12 & 13 & 12 & 14 & 16 & 28 \\
\hline & & 9. 3 & & 8 & 8 & $\mathrm{M}$ & 12 & $<6$ & 21 & $<6$ & 6 & 9 & e 16 & 11 & 9 & 80 \\
\hline & & 14.3 & $\mathrm{~d}<6$ & 8 & 10 & $<6$ & 16 & $\mathrm{~d}<6$ & 28 & 13 & 10 & 10 & 24 & 13 & 10 & 74 \\
\hline
\end{tabular}

a Each ounce per square foot corresponds to an average penetration of 0.0014 inch.

b Exposed for $1.0 \mathrm{yr}$ only.

c Data for the individual specimens differed from the average by more than $50 \%$.

d Data for 4 specimens.

In preparing the curves shown in this figure, values for average penetration, calculated from the data for weight loss given in table $4,{ }^{2}$ and for maximum penetration were plotted against the corresponding periods of exposure.

The curves for average penetration indicate that except in soils 60 and 63 , which are high in

\footnotetext{
${ }^{2}$ A verage penetration $($ mils $)=$ weight $\operatorname{loss} \frac{\left(\mathrm{oz} / \mathrm{ft}^{2}\right) \times 750}{\text { density }\left(\mathrm{lb} / \mathrm{ft}^{3}\right)} \cdot$

See tables 2 and 3 for the densities of the materials.
}

e Data for only 1 specimen-the other specimen was missing.

$\mathrm{f}$ These specimens had welded joints - data for only 1 specimen.

g M, shallow metal attack, roughening of the surface, but no definite pitting.

$\mathrm{h}+$, both specimens contained holes because of corrosion.

sulfides, and occasionally in other soils, the deoxidized copper $A$ and the copper-silicon alloys $\mathrm{D}, \mathrm{E}$, and $\mathrm{N}$, corroded at somewhat higher rates than the tough-pitch copper C.

Unlike the curves for average penetration, the pit depth-time curves for a number of the soils indicate that the deoxidized copper $\mathrm{A}$ and the copper-silicon alloys $\mathrm{D}$ and $\mathrm{N}$ did not pit any deeper than the tough-pitch copper C. In fact, only in soil 66 was tough-pitch copper significantly 
more resistant to pitting than the other materials. In all soils except 60 and 63 , the copper-silicon alloy E pitted considerably more than tough pitch copper.

\section{Copper-Zinc and Copper-Nickel-Zinc Alloys}

\section{Loss in Weight and Depth of Pitting}

The results of the corrosion tests of the copperzinc alloys and of a single copper-nickel-zinc alloy are given in table 5. Materials $\mathrm{H}, \mathrm{J}, \mathrm{K}$, and $\mathrm{L}$ were corroded in part by dezincification in certain of the soils, and some of the values for weight loss of these materials necessarily include some loss from this form of corrosion. However, as the corrosion product of spongy copper was not removed in measuring pits on dezincified areas, the values of maximum penetration given in the table are not affected by dezincification.

TABLE 5. Loss in weight and depth of maximum penetration of copper-zinc alloys and copper-nickel-zinc alloy

[A verage of two specimens]

\begin{tabular}{|c|c|c|c|c|c|c|c|c|c|c|c|c|c|c|c|c|c|}
\hline \multirow{3}{*}{$\begin{array}{c}\text { Iden- } \\
\text { tifi- } \\
\text { ca- } \\
\text { tion }\end{array}$} & \multirow[b]{3}{*}{ Material } & \multirow{3}{*}{$\begin{array}{c}\text { A ver- } \\
\text { age } \\
\text { expo- } \\
\text { sure }\end{array}$} & \multicolumn{15}{|c|}{ Test site number and soil type } \\
\hline & & & 51 & 53 & 55 & 56 & 58 & 59 & 60 & 61 & 62 & 63 & 64 & 65 & 66 & 67 & 70 \\
\hline & & & $\begin{array}{l}\text { Aca- } \\
\text { dia } \\
\text { clay }\end{array}$ & $\begin{array}{c}\text { Cecil } \\
\text { clay } \\
\text { loam }\end{array}$ & $\begin{array}{l}\text { Ha- } \\
\text { gers- } \\
\text { town } \\
\text { loam }\end{array}$ & $\begin{array}{c}\text { Lake } \\
\text { Charles } \\
\text { clay }\end{array}$ & Muck & $\begin{array}{c}\text { Carl- } \\
\text { isle } \\
\text { muck }\end{array}$ & $\begin{array}{l}\text { Rifle } \\
\text { peat }\end{array}$ & $\begin{array}{l}\text { Shar- } \\
\text { key } \\
\text { clay }\end{array}$ & $\begin{array}{c}\text { Sus- } \\
\text { que- } \\
\text { hanna } \\
\text { clay }\end{array}$ & $\begin{array}{c}\text { Tidal } \\
\text { marsh }\end{array}$ & $\begin{array}{c}\text { Docas } \\
\text { clay }\end{array}$ & $\begin{array}{c}\text { Chino } \\
\text { silt } \\
\text { loam }\end{array}$ & $\begin{array}{l}\text { Mo- } \\
\text { have } \\
\text { fine } \\
\text { grav- } \\
\text { elly } \\
\text { loam }\end{array}$ & $\begin{array}{l}\text { Cin- } \\
\text { ders }\end{array}$ & $\begin{array}{c}\text { Mer- } \\
\text { ced } \\
\text { silt } \\
\text { loam }\end{array}$ \\
\hline \multicolumn{18}{|c|}{ LOSS IN WEIGHT (OUNCES PER SQUARE FOOT) a } \\
\hline \multirow{7}{*}{$\mathrm{C}$} & \multirow{7}{*}{ Tough-pitch copper -. } & $\begin{array}{c}\text { Years } \\
2.0\end{array}$ & 0.42 & 0.12 & 0.14 & 0.12 & 0.13 & & 1.37 & b 0.09 & 0.15 & 1.31 & 0.67 & 0.50 & 0.11 & 3.15 & \\
\hline & & 5.4 & .91 & .16 & .19 & .34 & 1. 40 & 0.13 & 4. 68 & .34 & .26 & 2.99 & .96 & .47 & .16 & 8.04 & \\
\hline & & 7.4 & .35 & .23 & .17 & .60 & 1. 66 & c. 09 & 1.03 & .37 & .33 & 4. 33 & 1. 56 & .55 & .32 & 1. 42 & \\
\hline & & 9.3 & ..... & .24 & .20 & .71 & 1. 95 & .12 & 7. 26 & .33 & .36 & 4. 46 & 2. 80 & .26 & .45 & 9.84 & \\
\hline & & 14.3 & d. 46 & .23 & .16 & .61 & 1. 98 & d. 19 & с 14.66 & .58 & .49 & 8.31 & 1.04 & .47 & .27 & 6. 71 & \\
\hline & & 2.0 & .33 & .12 & .13 & .11 & 0.12 & & 1.47 & .11 & .15 & 0.55 & 0.33 & .52 & .18 & 3.36 & \\
\hline & & 5.4 & .97 & .16 & .22 & .34 & 1. 44 & .17 & 4. 11 & .38 & .27 & .54 & .33 & .27 & .32 & 12. 95 & \\
\hline \multirow[t]{5}{*}{$\mathrm{F}$} & \multirow[t]{3}{*}{ Red brass _. } & 7. 4 & .45 & .25 & .16 & .64 & 1. 43 & c. 12 & 0.80 & .49 & .39 & 1.10 & .52 & .58 & .48 & 2.37 & \\
\hline & & 9.3 & & .25 & .25 & .70 & 2. 06 & .12 & 3. 55 & .41 & .43 & 0.75 & e 1.12 & .28 & .77 & 8.46 & \\
\hline & & 14.3 & d. 61 & .28 & .18 & .65 & 2. 46 & d. 24 & с 13.04 & .69 & .43 & e 1.88 & 0.78 & .60 & .63 & 18. 73 & \\
\hline & & (2.0 & .28 & .12 & .12 & .07 & 0.15 & & 1.38 & b. 12 & .18 & 0.64 & .08 & .17 & .20 & 2.08 & \\
\hline & & 5.4 & .88 & .14 & .20 & .33 & e 1.35 & .14 & 3.64 & .33 & .31 & 2. 89 & .10 & .29 & .37 & 2.87 & \\
\hline \multirow[t]{5}{*}{ G } & Copper-n!ckel-zinc alloy _ & 7.4 & .45 & .29 & .15 & .56 & 1. 22 & c. 08 & 0.92 & .69 & .44 & 2.85 & .27 & .43 & .38 & 1.25 & \\
\hline & & 9.3 & ..... & .27 & .20 & .78 & 1. 40 & .09 & 3.61 & .43 & .47 & 3.55 & c. 74 & .44 & ๑. 60 & 6. 28 & \\
\hline & & (14.3 & d. 58 & .39 & .18 & .68 & 1. 70 & d. 17 & 10. 23 & .94 & .60 & 5. 61 & .59 & .54 & .54 & 3.55 & \\
\hline & & (2.0 & .32 & .14 & .15 & .08 & 0.19 & 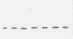 & 1. 13 & b. 17 & .20 & 0.25 & .02 & .31 & .23 & 5. 55 & \\
\hline & & 5.4 & 1. 07 & .21 & .25 & .29 & 2. 16 & .10 & 3. 56 & .60 & .36 & .11 & .24 & .34 & .43 & 14.71 & \\
\hline \multirow[t]{5}{*}{$\mathrm{H}$} & Admiralty metal & 7.4 & 0.57 & .29 & .23 & .46 & 1. 87 & .10 & 1.16 & .77 & .43 & .18 & .40 & .87 & .44 & 2. 96 & \\
\hline & & 9.3 & & .29 & .25 & .57 & 2. 09 & .09 & с 2.85 & .51 & .53 & .18 & .98 & .58 & .80 & 8. 27 & \\
\hline & & 14.3 & d. 73 & .35 & .24 & .64 & 2. 91 & d. 16 & c 8.98 & 1.18 & .62 & .22 & .73 & .78 & .79 & 17.15 & \\
\hline & & 2.0 & .17 & .25 & .20 & .16 & 0.25 & & 1. 14 & b 0.11 & .29 & .47 & .24 & .14 & .25 & 6.85 & \\
\hline & & 5.4 & .36 & .33 & .25 & .32 & 1. 10 & .15 & 2. 97 & .56 & .55 & .15 & .21 & c 1.00 & c. 82 & ${ }^{1} \mathrm{D}$ & \\
\hline \multirow[t]{5}{*}{$\mathrm{K}$} & Leaded silicon brass & 7.4 & .50 & .48 & .27 & .48 & 1. 59 & c. 10 & 0.85 & .61 & .55 & .35 & .80 & 1.03 & c 1.24 & $\mathrm{D}$ & \\
\hline & & 9.3 & & .47 & .36 & .89 & e 1.66 & .20 & c 3.22 & .87 & .71 & c. 52 & - 1.07 & 1. 39 & 0.95 & D & \\
\hline & & (14.3 & d. 48 & .58 & .37 & .76 & 3. 76 & d. 24 & c12. 30 & 1. 89 & .71 & .51 & 0.68 & 1. 50 & .84 & $\mathrm{D}$ & \\
\hline & & 2.0 & .33 & .10 & .18 & .08 & 0.21 & & 1. 71 & b 0.11 & .22 & .04 & .57 & 1. 37 & .35 & 16. 56 & \\
\hline & & 5.4 & 1.41 & .22 & .34 & .38 & 1. 52 & .01 & 5. 14 & 1.00 & .55 & .02 & 1.31 & 1. 17 & .92 & $\mathrm{D}$ & \\
\hline \multirow[t]{5}{*}{$\mathrm{J}$} & Yellow brass & 7.4 & 0.79 & .42 & .37 & .74 & 2. 20 & .01 & 1. 52 & 1.35 & .51 & .07 & 2.11 & 3. 10 & .88 & $\mathrm{D}$ & \\
\hline & & 9.3 & & .41 & .30 & .94 & 3. 33 & .03 & - 4.21 & 1.22 & .94 & .08 & 1.94 & 1.60 & ॰ 1.16 & D & \\
\hline & & 14.3 & d 1.23 & .51 & .39 & .91 & 3. 98 & d. 02 & e 27.30 & 2. 42 & .75 & .08 & 1.66 & 2. 52 & 0.96 & D & \\
\hline & & 2.0 & 0.68 & .19 & .19 & .14 & 0.20 & & 1. 73 & b 0.16 & .33 & .14 & 4. 02 & 2. 43 & .63 & D & \\
\hline & & 5. 4 & 1. 45 & .30 & o. 58 & .46 & 3.47 & .02 & 4. 42 & 1. 75 & 1. 20 & .06 & 6.91 & 1. 56 & 1.68 & $\mathrm{D}$ & \\
\hline \multirow[t]{3}{*}{$\mathrm{L}$} & Muntz metal & 7.4 & 1. 04 & .61 & .66 & .71 & 4. 61 & .02 & 1. 43 & 2. 97 & 1.08 & .09 & 9.79 & 3. 38 & 1.50 & $\mathrm{D}$ & \\
\hline & & 9.3 & . & .52 & .77 & 1.21 & 5. 25 & .03 & c 4.56 & 2. 58 & 1. 79 & .10 & 11.53 & 1.45 & 1.41 & D & \\
\hline & & 14.3 & d 1.19 & 62 & .65 & 1.43 & 4. 83 & d. 03 & с20. 43 & 4. 21 & 1.10 & .09 & 15.38 & 1. 73 & 2. 06 & D & \\
\hline
\end{tabular}

See footnotes at end of table. 
TABLE 5. Loss in weight and depth of maximum penetration of copper-zinc alloys and copper-nickel-zinc alloy-Continued

(A verage of two specimens)

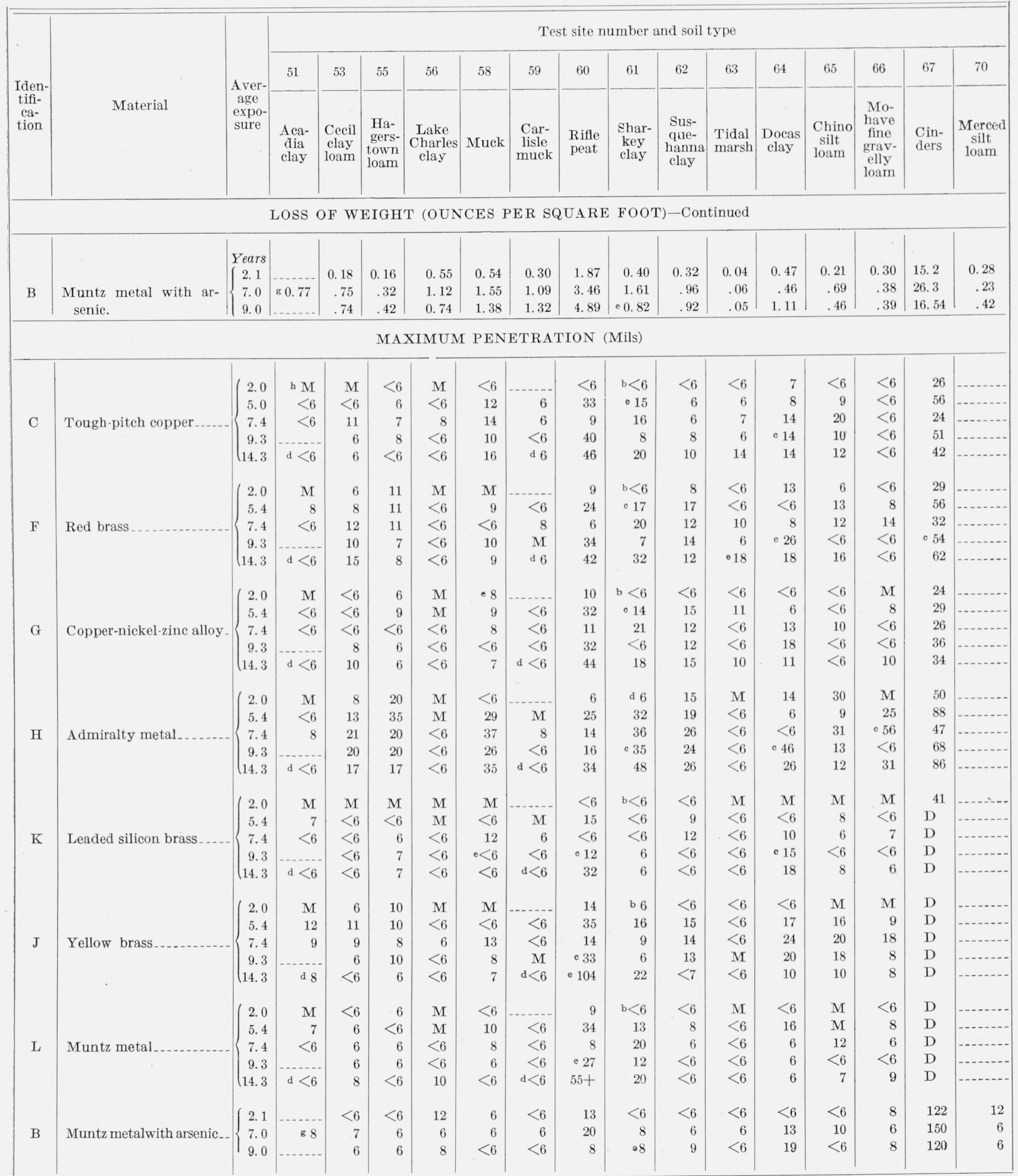

a Each ounce per square foot corresponds to an average penetration of 0.0014 in. e Data for only 1 specimen. The other specimen was missing.

b Exposed for 1.0 yr only.

f $\mathrm{D}$, specimens destroyed by dezincification.

- Data for the individual specimens differed from the average by more than $50 \%$. g Data for 10 specimens.

d Data for 4 specimens.

h $\mathrm{M}$, shallow metal attack, roughening of the surface, but no definite pitting. 
Because the porous deposit produced by dezincification is the product of one process of corrosion, complete evaluation of the condition of a corroded specimen in terms of weight loss and pitting necessarily entails removal of the dezincified corrosion product. ${ }^{3}$ However, in the present study, it was desired to distinguish between weight loss and pitting due to dezincification, and that resulting from other corrosion processes. Consequently, in order to exclude from present consideration the corrosion that resulted from dezincification, weight loss data for materials appreciably affected by dezincification were not used in plotting the average penetration-time curves shown in figure 5 . For comparison with the corrosion of copper, the corrosion-time curves for tough-pitch copper $\mathrm{C}$ are included in the figure.

A progressive increase in average penetration with increasing zinc content is indicated by the curves, except for the soils high in sulfides. In those sulfide soils (59 and 63), which are continuously saturated throughout the year, the average penetration tends to increase inversely with the zinc content. This tendency is also indicated by the data for soil 60 ; but because of seasonal drying and consequent oxidation of sulfides to sulfates, this trend is not so pronounced. The relatively high resistance of the high-zine brasses to corrosion by sulfur compounds in other environments has been previously observed [3]. It should be noted that the high values for materials $\mathrm{J}$ and $\mathrm{L}$ for the final period, which indicate a departure from the inverse order, are unaffected by dezincification. As will be seen later, this form of corrosion was not observed in any of the soils high in sulfides.

The pit depth-time curves shown in figure 5 do not indicate any correlation between maximum penetration and zinc content. Instead of showing greater resistance to pitting than any of the copper-zinc alloys, as might have been predicted from the average penetration-time curves, toughpitch copper $\mathrm{C}$ and red brass $\mathrm{F}$ occupy an intermediate position in all soils with the exception of soils 51,56 , and 66 , in which they are as resistant as any of the other materials. It is surprising that the alloys that showed the maximum and minimum tendency toward pitting, namely mate-

\footnotetext{
3 Methods for removal of products of dezincification without loss of uncorroded metal are currently under investigation.
}

rial $\mathrm{H}(67.08 \%$ of $\mathrm{Cu}, 31.07 \%$ of $\mathrm{Zn}, 1.01 \%$ of $\mathrm{Si}$, and $0.84 \%$ of $\mathrm{Pb})$ and material $\mathrm{K}(71.28 \%$ of $\mathrm{Cu}, 27.39 \%$ of $\mathrm{Zn}$, and $1.30 \%$ of $\mathrm{Sn}$ ) should differ so little in composition.

\section{Dezincification}

Although the extent of dezincification of the materials subject to this form of corrosion was indicated qualitatively in earlier progress reports, measurements of dezincification have not previously been made in the course of this investigation. In the present study, the depth of dezincification was measured in the following manner. The specimens were first cut longitudinally and examined for evidence of dezincification. They were then cut into transverse sections so that the areas having the maximum depth of dezincification could be located. Measurements of the depth of dezincification were made independently by two observers with the aid of magnifying lenses and were recorded as percentage of the wall thickness, after which the measurements were converted into mils. In order to check the accuracy of this procedure, the depth of dezincification was measured directly on photographs of transverse sections enlarged 15 magnifications. Agreement between the two methods was excellent.

The form and depth of dezincification on materials $\mathrm{B}, \mathrm{H}, \mathrm{K}, \mathrm{J}$, and $\mathrm{L}$ are shown in table 6 . The specimens of red brass $\mathrm{F}$, and copper-nickelzinc alloy $\mathrm{G}$ did not dezincify in any of the soils. A tranverse section of a typical dezincified area of a Muntz metal specimen removed from Sharkey clay (soil 61) is shown in figure 6 .

The microstructures of a partially dezincified section of a leaded silicon brass specimen removed from the same soil is shown in figure 7 .

From the extent of dezincification indicated by the data of table 6 , it is evident that the values of weight loss and maximum penetration given in table 5 may be entirely misleading as measures of the extent of deterioration of these materials. On the basis of the values for weight loss and maximum penetration, one might conclude that a certain low-copper alloy is highly resistant to corrosion; whereas data for dezincification might indicate actual failure. If, for example, only the values for average and maximum penetration tabulated below are considered, one would conclude that 
TABLE 6. Maximum depth of dezincification on brasses exposed for 14 years a

+ , one or both specimens dezincified through wall thickness of pipe.

$\mathrm{P}$, plug type of dezincification.

$\mathrm{U}$, uniform type of dezincification.

\begin{tabular}{|c|c|c|c|c|c|c|c|c|c|c|}
\hline \multirow{4}{*}{$\begin{array}{l}\text { Soil } \\
\text { No. }\end{array}$} & \multicolumn{2}{|c|}{ Admiralty metal } & \multicolumn{2}{|c|}{$\begin{array}{l}\text { Leaded silicon } \\
\text { brass }\end{array}$} & \multicolumn{2}{|c|}{ Yellow brass } & \multicolumn{2}{|c|}{ Muntz metal } & \multicolumn{2}{|c|}{$\begin{array}{l}\text { Muntz metal with } \\
\text { arsenic }\end{array}$} \\
\hline & \multicolumn{2}{|c|}{$\begin{array}{l}71.28 \% \mathrm{Cu} \\
27.39 \% \mathrm{Zn} \\
1.30 \% \mathrm{Sn}\end{array}$} & \multicolumn{2}{|c|}{$\begin{array}{c}67.08 \% \mathrm{Cu} \\
31.07 \% \mathrm{Zn} \\
0.84 \% \mathrm{~Pb} \\
1.01 \% \mathrm{Si}\end{array}$} & \multicolumn{2}{|c|}{$\begin{array}{r}66.50 \% \mathrm{Cu} \\
33.06 \% \mathrm{Zn} \\
0.42 \% \mathrm{~Pb}\end{array}$} & \multicolumn{2}{|c|}{$\begin{array}{r}60.06 \% \mathrm{Cu} \\
39.58 \% \mathrm{Zn} \\
0.36 \% \mathrm{~Pb}\end{array}$} & \multicolumn{2}{|c|}{$\begin{array}{r}62.37 \% \mathrm{Cu} \\
37.54 \% \mathrm{Zn} \\
0.08 \% \mathrm{As}\end{array}$} \\
\hline & \multicolumn{2}{|l|}{$\mathrm{H}$} & \multicolumn{2}{|l|}{$\mathrm{K}$} & \multicolumn{2}{|l|}{$\mathrm{J}$} & \multicolumn{2}{|l|}{$\mathrm{L}$} & \multicolumn{2}{|l|}{$\mathrm{B}$ b } \\
\hline & $\begin{array}{l}\text { Maximum } \\
\text { depth }\end{array}$ & Type & $\begin{array}{l}\text { Maximum } \\
\text { depth }\end{array}$ & Type & $\begin{array}{l}\text { Maximum } \\
\text { depth }\end{array}$ & Type & $\begin{array}{l}\text { Maximum } \\
\text { depth }\end{array}$ & Type & $\begin{array}{c}\text { Maximum } \\
\text { depth }\end{array}$ & Type \\
\hline 51 & 0 & .... & $\begin{array}{l}\text { Mils } \\
\text { с } 60+\end{array}$ & $\mathrm{U}$ & $\begin{array}{l}\text { Mils } \\
38\end{array}$ & $\mathrm{P}$ & $\begin{array}{l}\text { Mils } \\
73+\end{array}$ & $\mathrm{U}$ & $\begin{array}{c}\text { Mils } \\
0\end{array}$ & -... \\
\hline 53 & 0 & ... & 6 & $\mathrm{U}$ & 18 & $\mathrm{U}$ & 0 & -... & 0 & $\ldots$ \\
\hline 55 & 0 & -..- & d 10 & $\mathrm{U}$ & 0 & .... & 0 & $\ldots$ & 0 & -.. \\
\hline 56 & 0 & -..- & 0 & $\ldots$ & d 14 & $\mathrm{P}$ & 68 & $\mathrm{U}$ & 0 & -. - \\
\hline 58 & 0 & $-\cdots$ & $48+$ & $\mathrm{U}$ & 66 & $\mathrm{U}$ & $80+$ & $\mathrm{U}$ & 0 & -... \\
\hline 59 & 0 & -..- & 0 & $\ldots$ & 0 & .... & 0 & .... & 0 & - - - \\
\hline 60 & 0 & .... & 0 & -... & 0 & -... & 0 & -..- & 0 & ... \\
\hline 61 & 0 & -... & $80+$ & $\mathrm{U}$ & 80 & $\mathrm{P}$ & 32 & $\mathrm{U}$ & 0 & $\ldots$ \\
\hline 62 & 0 & .... & 28 & U & 22 & $\mathrm{P}$ & 4 & $\mathrm{U}$ & 0 & .... \\
\hline 63 & 0 & .... & 0 & .... & 0 & -... & 0 & .... & 0 & .... \\
\hline 64 & d 22 & U & 28 & $\mathrm{P}$ & 50 & $\mathrm{U}$ & $80+$ & $\mathrm{U}$ & 0 & .... \\
\hline 65 & 7 & $\mathrm{P}$ & $80+$ & $\mathrm{U}$ & 76 & $\mathrm{U}$ & $80+$ & $\mathrm{U}$ & 0 & -... \\
\hline 66 & d $72+$ & $\mathrm{P}$ & d $40+$ & $\mathrm{U}$ & 26 & $\mathrm{U}$ & $72+$ & $\mathrm{U}$ & 0 & -... \\
\hline 67 & 0 & $\ldots$ & $80+$ & $\mathrm{U}$ & $145+$ & $\mathrm{U}$ & $80+$ & $\mathrm{U}$ & e 0 & -... \\
\hline 70 & - & -... & -........ & -..- & ......... & -... & - & -... & 0 & ...- \\
\hline
\end{tabular}

a Average for 2 specimens except in soils 51 and 59, which represent the average for 4 specimens.

b The arsenical Muntz metal specimens (B) were exposed for $9 \mathrm{yr}$.

c A verage of 3 specimens. The other specimen was unaffected by dezincification.

d Only one specimen affected by dezincification. The other specimen was unaffected.

e Intergranular corrosion.

materials $\mathrm{H}$ and $\mathrm{K}$ are equally resistant to corrosion in soil 51. However, when dezincification is

\begin{tabular}{|c|c|c|c|}
\hline \multirow{2}{*}{ Material } & \multicolumn{2}{|c|}{ Penetration } & $\begin{array}{c}\text { Depth of } \\
\text { dezincifi- } \\
\text { cation }\end{array}$ \\
\cline { 2 - 3 } & Average & Maximum & \\
\hline & Mils & Mils & Mils \\
H & 1.0 & 6 & 0 \\
K & 0.7 & 6 & $60+$ \\
J & 1.7 & 8 & 38 \\
L & 1.7 & 6 & $73+$ \\
& & & \\
\hline
\end{tabular}

considered, it is evident that the values for penetration define accurately the condition of material $\mathrm{H}$ only, because material $\mathrm{K}$ has been entirely dezincified. Similarly, the condition of materials $\mathrm{J}$ and $\mathrm{L}$ is indicated more accurately by the data for dezineification than for penetration.

Dezincification of the two-phase copper-zinc alloys, $\mathrm{K}$ and $\mathrm{L}$, and the single-phase copper-zinc alloy, J, was fairly general, the specimens of these alloys being dezincified to some extent in most of the soils (table 6). The much greater dezincification of these alloys than of the single-phase alloy, $\mathrm{H}$, was, of course, to be expected. Although the surface of the specimens of the arsenic bearing 60-40 brass B, showed incipient dezincification after exposure for $2 \mathrm{yr}$, careful examination of the specimens of this material exposed for 7 and for $9 \mathrm{yr}$ indicated that this effect was entirely superficial.

Arsenical brasses normally exhibit good resistance to dezincification, but occasionally they undergo intergranular corrosion in environments other than soils [3]. Specimens of arsenic-bearing brass $\mathrm{B}$ were carefully examined after exposure, and only in those that had been exposed to cinders at site 67 was intergranular corrosion observed (fig. 8).

Superficial dezincification of arsenical brass B, red brass $\mathrm{F}$, and of the copper-zinc-nickel alloy $\mathrm{G}$ 
was reported in an earlier publication [1] to have been observed on specimens of these materials from all of the soils except 59 and 63 . However, as the surfaces so affected have shown no tendency to increase in depth with time, it is questionable whether the term dezincification should be applied to what is, in effect, mere surface discoloration.

It is evident that dezincification of brasses in soils is influenced not only by alloy composition, but by the nature of the environment as well. The occurrence and intensity of dezincification appear to be largely independent of the corrosiveness of the soils as measured by weight loss and depth of pits. For example, in the corrosive Rifle peat, soil 60 , materials $\mathrm{H}, \mathrm{K}$, J, and $\mathrm{L}$ showed no evidence of dezincification. The fact that dezincification did not occur in this and in other soils high in sulfides, 59 and 63 , shows that sulfides in high concentration act as inhibitors of dezincification.

\section{Soldered and Welded Joints in Copper}

Because lead-tin solders are anodic to copper, it is necessary to consider the possibility of galvanic corrosion of the solder when soldered joints are used in underground construction. Hiers [4] has reported that serious galvanic action between lead-tin solders and copper pipe may take place in sea water. During the soldering operation a copper-tin alloy cathodic to copper may be formed, providing thereby a source of galvanic corrosion of the copper [5].

For study of the galvanic action between copper and solder in soils, short sections of copper tubing were connected by means of standard sweated joints and soldered with 50-50 lead-tin solder. The joint consisted of two 6 -in. sections of tubing $1 \frac{1}{4}$ in. in diameter joined by a coupling $2 \frac{1 / 4}{4}$ in. in length. Streamlined caps were used to close the exposed ends. The solder was applied to the sweat fittings through one hole in each cap and two holes in the coupling.

Inspection of the soldered specimens from the 14 test sites after exposure for periods ranging up to $14 \mathrm{yr}$ showed no indication of galvanic corrosion of the solder. Neither was there evidence that corrosion had penetrated into the solder to an appreciable extent. In practically all of the soils to which the specimens were exposed, a dense hard coating or film of white corrosion products covered the entire surface of the exposed solder, which was thereby protected from further corrosion. These results are in agreement with those reported by Crampton [3] of tests of sweated joints made with various commercial solders when exposed for $2 \mathrm{yr}$ to a saline solution maintained at $60^{\circ} \mathrm{C}$. The results also agree with those obtained by Tracy [6] in 6-yr tests to determine the effect of hot circulating water, with and without carbon dioxide, on solders of different compositions.

An additional source of galvanic corrosion of copper arises from the possibility that oxides formed in welding operations may impart to the weld a potential that is cathodic to a pickled copper surface. Specimens for study of the effect of welds on corrosion were prepared by joining two 6 -in. lengths of copper pipe, 1.5 in. in diameter, by means of a circumferential arc weld. The welding rod was of the same nominal composition as the pipe. Neither the depths of the maximum pits nor the distribution of corrosion on the welded specimens after exposure for $14 \mathrm{yr}$ (material $\mathrm{N}$, table 4) gave any indication of accelerated corrosion in the vicinity of the weld.

\section{Effect of Environment on the Corrosion of Copper}

The corrosion-time curves for copper and for the copper-silicon alloys that were used to study the effect of alloy composition on corrosion (fig. 4) indicate wide differences not only in the corrosiveness of the soils, but also in the progress of corrosion with time. The corrosion rates of tough pitch copper $\mathrm{C}$ in soils 55 and 56 for example, differ widely; but it is also noteworthy that in soil 55, corrosion practically ceased after a short period of exposure, whereas in soil 56 , it proceeded nearly in proportion to the duration of exposure.

For study of the effect of environment on the corrosion of copper, tough-pitch copper C, deoxidized copper $\mathrm{A}$, and the copper-silicon alloys $\mathrm{D}$ and $\mathrm{N}$ were considered as behaving essentially alike. By combining weight losses, expressed as average penetration, for two specimens of each of these four materials, average values of eight measurements were obtained for each soil for each of five periods of exposure. In the same manner, average values of maximum penetration were obtained for the different exposure periods and soils. 
In order to study the effect of environment in somewhat greater detail an equation of the form

$$
y=a x^{n},
$$

was employed for expressing the relation between corrosion and time.

Taking logarithms of both sides,

$$
\log y=\log a+n \log x .
$$

Expressing the logarithm of the pit depth as $\log$ $P$, the logarithm of the time as $\log T$, and the $y$-intercept as $\log k$ :

$$
\log P_{\max }=\log k+n \log T .
$$

By similar substitutions, a linear equation expressing the relation between average penetration and time was obtained:

$$
\log P_{\text {avg }}=\log k^{\prime}+u \log T \text {. }
$$

The slopes of these equations are given by the constants $n$ and $u$. The $y$-intercepts, $\log k$ and $\log k^{\prime}$, signify the logarithm of the maximum and average penetration at $1 \mathrm{yr}$, respectively. These equations were derived originally by Logan, Ewing, and Denison [7] and by Martin [8] to express, respectively, the progress with time of the pitting and weight loss of ferrous materials in soils. The equations have recently been employed in studying the effect of environment on the corrosion of ferrous metals in soils and in comparing the corrodibility of different ferrous metals and alloys [2]. Typical average penetration- and maximum penetration-time curves for copper on logarithmic coordinates are shown in figure 9 .

In table 7 are shown values for maximum and average penetration at $14 \mathrm{yr}$, computed by eq 3 and 4 , and for the respective constants. The standard errors of these constants computed according to the method of Ezekiel [9] are also given. The arrangement of the data is in the order of increasing values of the constant $u$.

In rating the soils in the order of corrosiveness, it is obviously necessary to consider not only the values of average and maximum penetration at $14 \mathrm{yr}$, but also the progress of corrosion with time as measured by the values of the constants $u$ and $n$. For example, although the average and maximum penetration of copper at $14 \mathrm{yr}$ in soils 58 and

\begin{tabular}{|c|c|c|c|c|c|c|c|c|c|c|c|c|c|c|c|c|}
\hline \multirow{2}{*}{\multicolumn{2}{|c|}{ Soil }} & \multirow{3}{*}{ Aeration } & \multicolumn{12}{|c|}{ Penetration } & \multirow{2}{*}{\multicolumn{2}{|c|}{$\begin{array}{l}\text { Pitting } \\
\text { factor b }\end{array}$}} \\
\hline & & & \multicolumn{6}{|c|}{ A verage } & \multicolumn{6}{|c|}{ Maximum } & & \\
\hline No. & Type & & $P_{T}=14 \mathrm{yr}$ & ${ }^{\sigma} P_{T}=14 \mathrm{yr}$ & $k^{\prime}$ & $\overline{\sigma k^{\prime}}$ & $u$ & $\sigma u$ & $P_{T}=14 \mathrm{yr}$ & $\bar{\sigma} P_{T}=14 \mathrm{yr}$ & $k$ & $\overline{\sigma k}$ & $n$ & $\sigma n$ & $\begin{array}{l}\text { Cop- } \\
\text { per }\end{array}$ & $\begin{array}{l}\text { Plain } \\
\text { iron } \\
\text { and } \\
\text { steel }\end{array}$ \\
\hline 65 & Chino silt loam. & Good ... & $\begin{array}{l}\text { Mils } \\
\quad 1.0\end{array}$ & $\begin{array}{l}\text { Mils } \\
\quad 0.4\end{array}$ & $\begin{array}{l}\text { Mils } \\
1.59\end{array}$ & $\begin{array}{r}\text { Mils } \\
1.35\end{array}$ & -0.18 & 0.40 & $\begin{array}{l}\text { Mils } \\
\quad 16.0\end{array}$ & $\begin{array}{l}\text { Mils } \\
\quad 4.3\end{array}$ & $\begin{array}{r}\text { Mils } \\
3.51\end{array}$ & $\begin{array}{c}\text { Mils } \\
1.8\end{array}$ & 0.57 & 0.26 & 16.0 & 5.3 \\
\hline 51 & Acadia clay ........ & Poor ...... & 0.8 & .3 & 0.63 & 0.45 & .10 & .36 & 4. 7 & 0.7 & 1. 73 & 0.46 & .38 & .14 & 5.9 & $\ldots$ \\
\hline 55 & Hagerstown loam. - & Good ....... & .3 & .02 & .17 & .02 & .26 & .04 & 7. 2 & .8 & 4. 74 & .96 & .16 & .10 & 24.0 & 15.8 \\
\hline 59 & Carlisle muck..... & Very poor & .3 & .05 & .11 & .07 & .36 & .28 & 5. 0 & .5 & 2. 35 & .97 & .28 & .17 & 16. 7 & 5. 7 \\
\hline 53 & Cecil clay loam.... & Good...... & .5 & .03 & .15 & .02 & .45 & .06 & 7. 8 & .9 & 2. 69 & .60 & .40 & .11 & 15. 6 & 11.8 \\
\hline 66 & $\begin{array}{l}\text { Mohave fine grav- } \\
\text { elly loam. }\end{array}$ & Fair..... & .9 & 2 & .26 & .12 & .45 & .22 & 10.1 & .9 & 7. 43 & 1. 6 & .12 & .11 & 11. 2 & 4. 5 \\
\hline 67 & Cinders. . . & Very poor & 15.1 & 8.6 & 4. 40 & 5.4 & .47 & .52 & 64.7 & 21 & 31. 7 & 21.0 & .27 & .32 & 4.3 & -... \\
\hline 62 & Susquehanna clay.- & Fair....... & 0.8 & 0.03 & 0.19 & 0.02 & .54 & .04 & 9.6 & 2.8 & 4. 04 & 1.00 & .33 & .12 & 12.0 & 7.8 \\
\hline 64 & Docas clay ......... & $\ldots$ do $\ldots . .$. & 4. 7 & .9 & .84 & .29 & .67 & .17 & 15.1 & 7. 1 & 7.04 & 2. 0 & .29 & .14 & 3.2 & 1.6 \\
\hline 61 & Sharkey clay & Poor ....... & 1.0 & .2 & .14 & .04 & .69 & .07 & 15.4 & 3.1 & 3. 60 & 1. 08 & .55 & .15 & 15.4 & 6. 4 \\
\hline 60 & Rifle peat $\ldots$ & $\ldots$ do $\ldots . . .$. & 8.6 & 5.8 & .88 & 1.30 & .86 & .60 & 31.2 & 14. 6 & 3. 00 & 2. 86 & .89 & .43 & 3.6 & 2.0 \\
\hline 63 & Tidal marsh & Very poor & 9.9 & .03 & .95 & 0.05 & .88 & .03 & 11. 2 & 2. 6 & 1.83 & 0.88 & .68 & .23 & 1.1 & 6.8 \\
\hline 56 & Lake Charles clay.- & Poor...... & 1. 2 & .2 & .10 & .03 & .96 & .16 & 4. 9 & 1. 0 & 1.88 & .72 & .37 & .19 & 4. 1 & 4.1 \\
\hline 58 & Muck & $\ldots$ do $\ldots \ldots$ & 4.9 & 1. 6 & .09 & .06 & 1.52 & .31 & 19.0 & 3.0 & 1. 28 & .40 & 1.02 & .16 & 3.9 & 6.0 \\
\hline
\end{tabular}
64 is roughly the same, the values of the constants

TABLE 7. Corrosion of copper at 14 years and constants of equations connecting average and maximum penetration with duration of exposure a

a $P=k\left(k^{\prime}\right) T^{n}(u)$, where $P=$ average or maximum penetration at the time, $T$.

b Pitting factor $=\frac{\text { maximum penetration }}{\text { average penetration }}$. 
$u$ and $n$ for soil 64 , namely 0.67 and 0.29 , respectively, indicate decreasing rates of corrosion with time; whereas the corresponding values of these constants for soil 58, namely, 1.52 and 1.02, respectively, indicate rates of corrosion at least proportional to time. On the basis of inherent corrosivity, as indicated by values of average and maximum penetration at $1 \mathrm{yr} \quad\left(k^{\prime}=0.09 \mathrm{mils}\right.$, $k=1.28$ mils), soil 58 would be considered the least corrosive of any of the soils with respect to both weight loss and pitting. However, because the rate of corrosion in this soil was continuously maintained over the period of the test the total corrosion at the end of $14 \mathrm{yr}$ was exceeded by only three soils, 60, 63, and 67 .

Comparison of the values of the constant $u$ with the aeration of the soils indicates that the rate of average penetration tended to decrease most rapidly in the better aerated soils. However, the fact that the values of $u$ are small in two poorly aerated soils, 51 and 59 , indicates that abundance of oxygen is not the sole factor that tends to diminish the rate of average penetration of copper in soils. Deposits of difficultly soluble salts on copper would be expected to have a similar effect.

The conditions that have the most corrosive action on copper are cinders (soil 67) sulfides (soils 60 and 63), and those factors that prevent the formation of protective films, such as carbon dioxide in excess, and high concentrations of hydrogen ions (soils 58 and 60). High concentrations of chloride are also corrosive to copper (soil 64).

It was previously stated that the smooth appearance of the specimens from many of the soils gave the impression that copprr, unlike iron and steel, tended to corrode uniformly (fig. 3). However, the values of the ratios of the maximum to the average penetration (pitting factor) recorded in table 7 indicate an even greater tendency for copper to corrode locally in certain soils than plain irons and steels.

\section{Zinc}

The corrosion of zinc is illustrated by photographs of specimens of rolled zinc exposed at the test sites for $11 \mathrm{yr}$ (fig. 10). Weight losses and maximum depths of pitting of both rolled and die-casting zinc are recorded in table 8 . Measured in terms of loss in weight, there is no significant difference in the corrosion of the two varieties of zinc. However, maximum penetration of rolled zinc was definitely less than die-casting zinc, except in soil 65, and in those soils in which both materials failed or in which the differences are too small to be considered significant.

For study of the effect of soil properties on the corrosion of zinc, values for average and maximum penetration of rolled zinc at $11 \mathrm{yr}$ were calculated by means of the equation previously used in studying the corrosion of copper. The constants of this equation, which is linear on logarithmic coordinates, were computed by the method of least squares. Values of the constants $k^{\prime}(k)$ and $u(n)$, representing the $y$-intercept and the slope, respectively, are recorded in table 9 . The arrangement is in the order of decreasing average penetration at $11 \mathrm{yr}$. Because of the severe corrosion of the zinc specimens in cinders, values for site 67 could not be computed.

The poorly and very poorly aerated soils are, as a class, corrosive to zinc, although high average penetration is not necessarily associated with deep pitting, as in soil 51. Soils of fair to good aeration containing high concentrations of chlorides and sulfates induce relatively deep pitting $(64,65$, and 66). A probable explanation for this accelerated pitting is that soluble salts diminish anodic polarization. The rather severe corrosion in soil 70 is to be attributed to the highly alkaline reaction of this soil ( $\mathrm{pH}$ 9.4) as well as to its content of soluble salts. The effect of soil reaction on the corrosion of zinc is further indicated by the very large values for average and maximum penetration in soil $60(\mathrm{pH}=2.6)$.

The values of the constants $u$ and $n$, which range between approximately zero and unity, indicate that corrosion of zinc may vary between a linear rate and complete cessation. However, as there is no correlation between the constants $k^{\prime}$ (k) and $u(n)$, a linear rate of corrosion will not result in severe corrosion unless the initial rate of corrosion is also high. No consistent variation of the constants with soil properties is indicated by the data. 
TABLE 8. Loss in weight and maximum penetration of zinc a

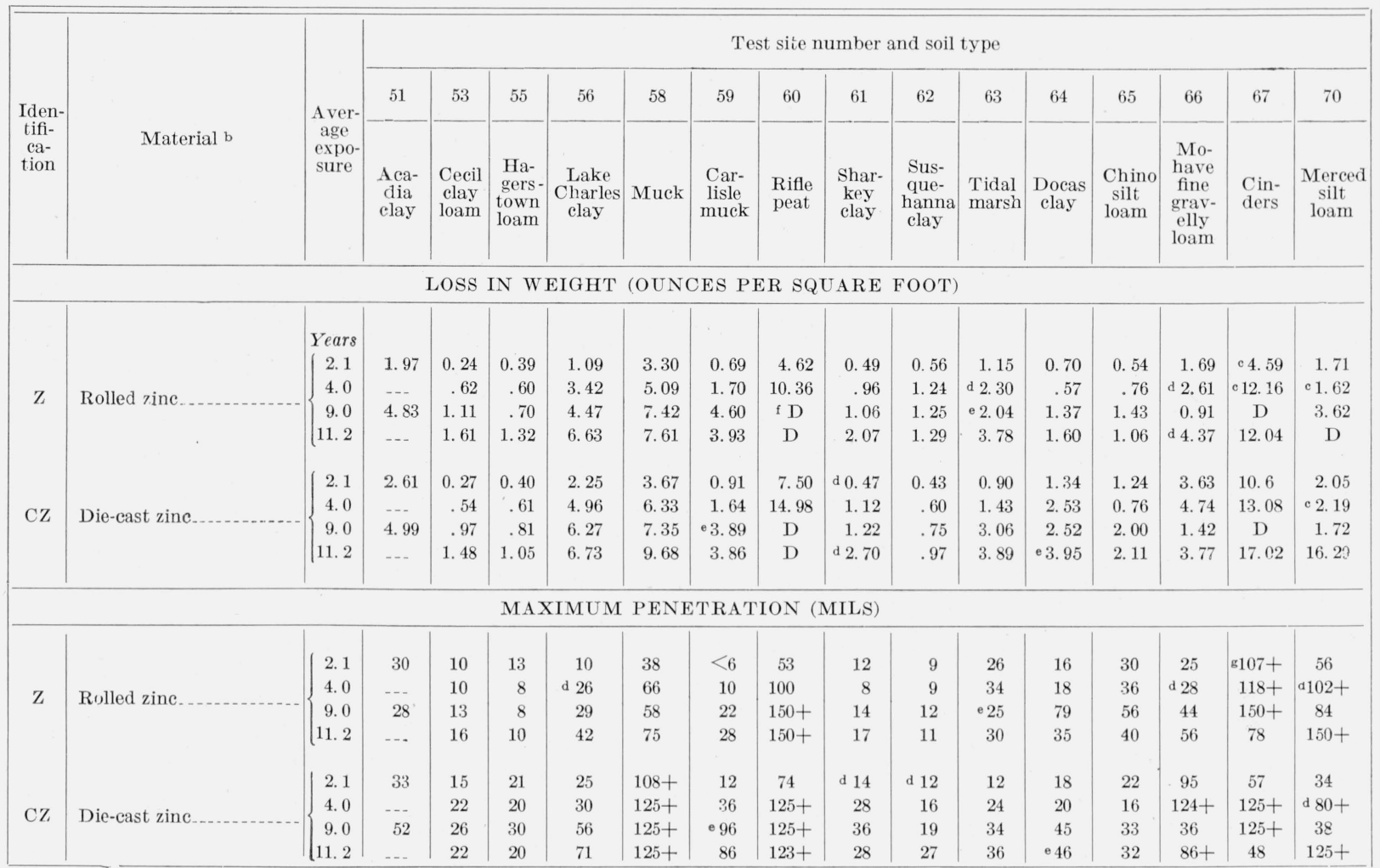

a Average loss in weight or depth of maximum penetration for 2 specimens except when indicated otherwise.

b See table 3 for composition of materials.

- Data for 1 specimen only. The other specimen was destroyed by corrosion.

d Data for the individual specimens differs from the average by more than $50 \%$.

e Data for 1 specimen only. The other specimen was missing.

I D, both specimens destroyed by corrosion.

$\mathrm{g}+$, one or both specimens contained holes due to corrosion

TABLE 9. Corrosion of rolled zinc at 11 years and constants of equations connecting average and maximum penetration with duration of exposure a

\begin{tabular}{|c|c|c|c|c|c|c|c|c|}
\hline \multirow{3}{*}{ No. } & \multirow{3}{*}{$\begin{array}{l}\text { Soil } \\
\text { Type }\end{array}$} & \multirow{3}{*}{ Aeration } & \multicolumn{6}{|c|}{ Penetration } \\
\hline & & & \multicolumn{3}{|c|}{ A verage } & \multicolumn{3}{|c|}{ Maximum } \\
\hline & & & $P_{T=11 \mathrm{yr}}$ & $k^{\prime}$ & $u$ & $P_{T=11 \mathrm{yr}}$ & $k$ & $n$ \\
\hline 60 & Rifle peat.. & Poor & $\begin{array}{l}\text { Mils } \\
61.4\end{array}$ & $\begin{array}{c}\text { Mils } \\
3.05\end{array}$ & 1.25 & $\begin{array}{l}\text { Mils } \\
271\end{array}$ & $\begin{array}{l}\text { Mils } \\
25.5\end{array}$ & 0.99 \\
\hline 58 & Muck & do & 13.3 & 3. 96 & 0.50 & 72 & 34.1 & .31 \\
\hline 56 & Lake Charles clay & Very poor & 10.8 & 1.07 & .97 & 40 & 7.0 & .73 \\
\hline 51 & Acadia clay & Poor & 9.1 & 2.08 & .62 & 28 & 31.1 & -.05 \\
\hline 59 & Carlisle muck & Very poor & 7. 7 & 0.56 & 1.09 & 27 & 2.9 & .92 \\
\hline 70 & Merced silt loam & Fair & 6.0 & 1. 67 & 0.54 & 89 & 45.5 & .28 \\
\hline 63 & Tidal marsh & Very poor & 5.3 & 1. 42 & .54 & 29 & 28.4 & .003 \\
\hline 66 & Mohave fine gravelly loam & Fair & 3.8 & 2. 66 & .15 & 49 & 15.5 & .50 \\
\hline 61 & Sharkey clay & Poor & 3.1 & 0.51 & .71 & 15 & 8.0 & .26 \\
\hline 53 & Cecil clay loam & Good & 2.6 & .20 & 1.08 & 15 & 7.6 & .27 \\
\hline 64 & Docas clay & Fair..... & 2.4 & .61 & 0.58 & 53 & 7. 9 & .79 \\
\hline 62 & Susquehanna clay ..... & ...... do & 2.4 & .82 & .44 & 11 & 7.7 & .17 \\
\hline 65 & Chino silt loam & Good ....... & 2.1 & .63 & .51 & 52 & 23.8 & .30 \\
\hline 55 & Hagerstown loam & ..... do...... & 1.7 & .45 & .57 & 8 & 12.5 & -.16 \\
\hline
\end{tabular}

a $P=k\left(k^{\prime}\right) T^{n(u)}$ 


\section{Lead}

Photographs of specimens of lead after exposure for $11 \mathrm{yr}$ are shown in figure 11. The losses in weight and depths of maximum pitting of four varieties of lead are given in table 10 . These data show fairly conclusively that neither the common impurities of lead, namely, copper and bismuth, nor the hardening agents, antimony and tellurium, have had any effect on its corrosion. The conclusion that these impurities and alloying constituents are without significant effect in the corrosion of lead in soils was drawn previously by
Burns [10] from the results of field tests of a wide variety of lead alloys in five typical soils of Indiana. The results of the present series of field tests may be considered to extend considerably the range of soil conditions to which the conclusions of Burns apply.

Because of the similarity in behavior of lead alloys $\mathrm{O}, \mathrm{T}$, and $\mathrm{B}$, corrosion data for a total of six specimens were averaged in obtaining the values recorded in table 11 . The values for average and maximum penetration at $11 \mathrm{yr}$, and the constants $k^{\prime}, k, u$, and $n$ were computed as described in the section on copper.

TABLE 10. Loss in weight and maximum penetration of lead alloys a

\begin{tabular}{|c|c|c|c|c|c|c|c|c|c|c|c|c|c|c|c|c|c|}
\hline \multirow{3}{*}{$\begin{array}{c}\text { Iden- } \\
\text { tifica- } \\
\text { tion }\end{array}$} & \multirow[b]{3}{*}{ Material b } & \multirow{3}{*}{$\begin{array}{l}\text { Aver- } \\
\text { age } \\
\text { expo- } \\
\text { sure }\end{array}$} & \multicolumn{15}{|c|}{ Test site number and soil type } \\
\hline & & & 51 & 53 & 55 & 56 & 58 & 59 & 60 & 61 & 62 & 63 & 64 & 65 & 66 & 67 & 70 \\
\hline & & & $\begin{array}{l}\text { Aca- } \\
\text { dia } \\
\text { clay }\end{array}$ & $\begin{array}{l}\text { Cecil } \\
\text { clay } \\
\text { loam }\end{array}$ & $\begin{array}{l}\mathrm{Ha}- \\
\text { gers- } \\
\text { town } \\
\text { loam }\end{array}$ & $\begin{array}{c}\text { Lake } \\
\text { Charles } \\
\text { clay }\end{array}$ & Muck & $\begin{array}{l}\text { Car- } \\
\text { lisle } \\
\text { muck }\end{array}$ & $\begin{array}{l}\text { Rifle } \\
\text { peat }\end{array}$ & $\begin{array}{l}\text { Shark- } \\
\text { ey clay }\end{array}$ & $\begin{array}{c}\text { Sus- } \\
\text { que- } \\
\text { hanna } \\
\text { clay }\end{array}$ & $\begin{array}{l}\text { Tidal } \\
\text { marsh }\end{array}$ & $\begin{array}{c}\text { Docas } \\
\text { clay }\end{array}$ & $\begin{array}{c}\text { Chino } \\
\text { silt } \\
\text { loam }\end{array}$ & $\begin{array}{c}\text { Mo- } \\
\text { have } \\
\text { fine } \\
\text { gravel- } \\
\text { ly } \\
\text { loam }\end{array}$ & $\begin{array}{l}\text { Cin- } \\
\text { ders }\end{array}$ & $\begin{array}{c}\text { Merced } \\
\text { silt } \\
\text { loam }\end{array}$ \\
\hline \multicolumn{18}{|c|}{ LOSS IN WEIGHT (OUNCES PER SQUARE FOOT) } \\
\hline \multirow{5}{*}{$\mathrm{O}$} & \multirow{5}{*}{ Chemical lead ... } & $\begin{array}{c}\text { Years } \\
2.1\end{array}$ & 0.62 & 0.22 & 0.37 & 0.21 & 1. 56 & 0.36 & 0.18 & 1. 46 & 0.30 & 0.05 & 0.20 & 0.14 & 0.10 & 3.67 & 0.03 \\
\hline & & 4. 0 & -..... & .21 & .20 & .45 & 2. 41 & .81 & .28 & 2. 21 & .93 & .02 & .19 & .13 & .10 & 12. 21 & .12 \\
\hline & & 9.0 & 3.06 & .53 & .37 & 2.02 & 2.49 & 1. 76 & .54 & 1. 22 & .67 & .10 & .46 & .45 & .34 & 11. 21 & .26 \\
\hline & & 11.2 & $\ldots-$ & .64 & .41 & 3.49 & 2.82 & 2.06 & .75 & 3.03 & .94 & .02 & .60 & .35 & .18 & 3.06 & .19 \\
\hline & & 2.1 & 1. 21 & .25 & .34 & 0.38 & 1. 68 & 0.23 & .15 & 1. 21 & .36 & .06 & .25 & .17 & .25 & 3.35 & .09 \\
\hline \multirow{4}{*}{$\mathrm{T}$} & \multirow{4}{*}{ Tellurium lead . } & 4. 0 & $\ldots$ & .31 & .28 & .82 & 2.80 & 1.08 & .20 & 1. 75 & .64 & c. 02 & .18 & .16 & .12 & 13.22 & .15 \\
\hline & & 9.0 & 3.82 & .73 & .54 & 2.30 & 2. 60 & 2.09 & .57 & 1. 44 & 1.37 & .13 & .48 & .59 & .58 & 11. 28 & .32 \\
\hline & & 11.2 & ..... & .67 & .57 & 4.60 & 3.47 & 1. 77 & .84 & 3. 40 & 1.00 & .02 & .88 & .40 & .36 & 3.42 & .28 \\
\hline & & 2.1 & 1.05 & .25 & .19 & 0.31 & 1.45 & 0.20 & .10 & 0.94 & 0.27 & .04 & .12 & .17 & .06 & 3.14 & .10 \\
\hline \multirow{3}{*}{ B } & \multirow{2}{*}{ Antimonial lead.......... } & 4. 0 & -...- & .22 & .15 & .50 & 2. 12 & 1.04 & .22 & 1. 75 & 1. 03 & .01 & .19 & .21 & .12 & 4. 21 & .14 \\
\hline & & 9.0 & 3.09 & .62 & .30 & 1.65 & 2. 24 & 1. 97 & .54 & 1. 16 & 0.77 & c. 05 & .45 & .51 & .28 & 12.27 & .20 \\
\hline & \multirow{3}{*}{ Special lead alloy } & 11.2 & & .70 & .35 & 4.54 & 3.02 & 1.09 & .79 & 3. 78 & 1. 24 & .01 & .96 & .35 & .20 & 4. 28 & .16 \\
\hline \multirow{2}{*}{ M } & & $\{5.0$ & & .43 & .17 & 0.52 & 0.54 & 1.23 & .74 & 0.82 & 0.69 & .18 & .50 & .42 & .24 & 1.18 & .35 \\
\hline & & | 7.2 & & d. 46 & .27 & 4.98 & .70 & 0.82 & d. 61 & d. 63 & d. 64 & .20 & .40 & .38 & .39 & 2.23 & .18 \\
\hline \multicolumn{18}{|c|}{ MAXIMUM PENETRATION } \\
\hline \multirow{5}{*}{$\mathrm{O}$} & \multirow{5}{*}{ Chemical lead.. } & 2.1 & 40 & 18 & 24 & 38 & 34 & 21 & 18 & 35 & 32 & 14 & 24 & 40 & 44 & 79 & 48 \\
\hline & & 4. 0 & & 12 & 26 & 37 & 28 & 15 & 15 & 39 & 29 & 18 & 16 & 24 & 34 & 104 & 14 \\
\hline & & 9.0 & 68 & 26 & 19 & 86 & 46 & 14 & 16 & 31 & 26 & 29 & 25 & 32 & 36 & 135 & 24 \\
\hline & & 11.2 & $\cdots$ & 18 & 31 & 100 & 52 & 20 & 33 & 70 & 34 & 12 & 25 & 15 & 24 & 85 & 24 \\
\hline & & 2.1 & 54 & 12 & 26 & 30 & 55 & 8 & 29 & 33 & 19 & 10 & 21 & 22 & 23 & 71 & 16 \\
\hline \multirow{4}{*}{$\mathrm{T}$} & \multirow{4}{*}{ Tellurium lead.. } & 4. 0 & & 20 & 26 & 48 & 56 & 12 & 10 & 30 & 31 & c 12 & 11 & 16 & 41 & 94 & 27 \\
\hline & & 9.0 & 66 & 18 & 26 & 110 & 33 & 18 & 36 & 43 & 25 & 32 & 20 & 21 & 30 & 104 & 37 \\
\hline & & 11.2 & $\cdots$ & 16 & 30 & 107 & 53 & 21 & 23 & 73 & 40 & 8 & 17 & 20 & 23 & 61 & 16 \\
\hline & & 2.1 & 56 & 10 & 26 & 39 & 50 & 9 & 6 & 31 & 12 & $<6$ & 12 & 6 & 12 & 56 & 11 \\
\hline \multirow{3}{*}{$\mathrm{B}$} & \multirow{3}{*}{ Antimonial lead. } & 4.0 & -.. & 10 & 18 & 52 & 58 & 7 & $<6$ & 42 & 30 & 16 & 12 & 15 & 15 & 90 & 12 \\
\hline & & 9.0 & 63 & 14 & 15 & 74 & 66 & 20 & 20 & 62 & 26 & • 44 & 10 & 26 & 24 & 125 & 20 \\
\hline & & 11.2 & & 9 & 16 & 104 & 51 & 12 & 28 & 89 & 14 & 6 & 19 & 7 & 16 & 46 & 9 \\
\hline \multirow{2}{*}{ M } & \multirow{2}{*}{ Special lead alloy ........ } & 5.0 & & 12 & 15 & 30 & 18 & 25 & 13 & 24 & 18 & 36 & 21 & 19 & 34 & 26 & 28 \\
\hline & & 7.2 & & d 13 & 8 & 58 & 8 & 8 & d 8 & d 18 & d 10 & 8 & 10 & 12 & 18 & 15 & 10 \\
\hline
\end{tabular}

a Average loss in weight or depth of maximum penetration for 2 specimens except when indicated otherwise.

b See table 3 for composition of materials.

c Data for 1 specimen only. The other specimen was missing.

d Data for 3 specimens. 
TABLE 11. Corrosion of lead of 11 years and constants of equations connecting average and maximum penetration with duration of exposure a

\begin{tabular}{|c|c|c|c|c|c|c|c|c|}
\hline \multirow{3}{*}{ No. } & \multirow{2}{*}{ Soil } & \multirow{3}{*}{ Aeration } & \multicolumn{6}{|c|}{ Penetration b } \\
\hline & & & \multicolumn{3}{|c|}{ Average } & \multicolumn{3}{|c|}{ Maximum } \\
\hline & Type & & $P_{T=11 \mathrm{yr}}$ & $k^{\prime}$ & $u$ & $P_{T-11 \mathrm{yr}}$ & $k$ & $n$ \\
\hline 67 & Cinders. & Very poor. & $\begin{array}{c}\text { mils } \\
7.54\end{array}$ & $\begin{array}{l}\text { mils } \\
4.64\end{array}$ & 0.20 & $\begin{array}{r}\text { mils } \\
89\end{array}$ & $\begin{array}{l}\text { mils } \\
74.3\end{array}$ & 0.08 \\
\hline 51 & Acadia day _.. & Poor & c 4.21 & 0.55 & $\begin{array}{r}0.20 \\
.85\end{array}$ & $\begin{array}{l}.9 \\
\text { с } 69\end{array}$ & 43.4 & $\begin{array}{r}.00 \\
.19\end{array}$ \\
\hline 56 & Lake Charles Clay & Very poor & 3.52 & .09 & 1. 54 & 101 & 20.6 & .66 \\
\hline 58 & Muck & Poor & 3. 07 & 1.64 & 0.26 & 50 & 43.7 & .06 \\
\hline 59 & Carlisle muck & Very poor-- & 2. 56 & 0.18 & 1. 11 & 17 & 9.7 & .24 \\
\hline 61 & Sharkey clay ....... & Poor & 2. 47 & 1. 00 & 0.38 & 61 & 23.3 & .42 \\
\hline 62 & Susquehanna clay & Fair & 1. 23 & 0.26 & .66 & 29 & 20.9 & .14 \\
\hline 60 & Rifle peat & Poor & 0.76 & .07 & 1.02 & 24 & 10.1 & .36 \\
\hline 53 & Cecil clay loam & Good & .70 & .14 & 0.69 & 20 & 12.0 & .13 \\
\hline 64 & Docas clay & Fair & .67 & .08 & .86 & 18 & 14.9 & .09 \\
\hline 65 & Chino silt loam & Good ....... & .47 & .09 & .68 & 18 & 23.7 & -.11 \\
\hline 55 & Hagerstown loam & do & 43 & .22 & .28 & 23 & 24.8 & -.04 \\
\hline 66 & Mohave fine gravelly loam. & Fair & .32 & .08 & .58 & 26 & 28.8 & -.05 \\
\hline 70 & Merced silt loam & _. do & .27 & .05 & .73 & 20 & 24.3 & -.09 \\
\hline 63 & Tidal marsh & Very poor & .04 & .04 & -.03 & 18 & 9.8 & .24 \\
\hline
\end{tabular}

a $P=k\left(k^{\prime}\right) T^{n(u)}$.

b Average of 3 lead alloys (see text).

c Data for 9 yr only.

The tendency for maximum penetration to decrease with increasing aeration of the soil, which has been seen to apply to plain irons and steels [2], and in the present paper to copper and zinc, is also to be observed in table 11. In fact, a fairly definite tendency for maximum penetration also to decrease with increasing aeration is indicated by the data. The exceptions to this trend, namely, the low corrosion rates for soils 60 and 63 , can be readily explained as being due to the inhibitive effect of sulfates in high concentration. The fact that severe corrosion of lead occurred in soil 51, likewise high in sulfates, does not necessarily weaken this explanation, because ions present in concentrations less than that required for passivation tend to accelerate the corrosion of lead [10]. The partially inhibitive effect of bicarbonate, chloride, and sulfate ions is indicated by the data for the group of alkaline soils of fair to good aeration, $64,65,66$, and 70 . In spite of their high contents of soluble salts these soils as a class are actually less corrosive than soils of similar aeration, which are low in soluble salts, namely, soils 53, 55, and 62 .

Comparison of the values of the constants $u$ and $n$ indicates that in general the rate of pitting of lead decreases considerably more rapidly than the rate of average penetration. In fact, except for several of the poorly aerated soils, the values of $n$ indicate virtually complete cessation of pitting during the 11-yr exposure period. It is reasonable to attribute this marked reduction in the rate of pitting to anodic polarization, which resulted from the deposition of difficult soluble corrosion products in close proximity to the anodic areas.

\section{Comparison of the Corrosion of Ferrous and Nonferrous Metals}

Because copper, zinc, and lead, together with iron and steel are the metals most commonly used for underground construction, a comparison of the corrosion resistances of these metals forms a basis for selecting materials according to their suitability for specific environmental conditions. Although zine is not ordinarily considered to be a material of construction, it is desirable to include it in the present study because of the extensive use of zinc underground as a protective coating for iron and steel and as an anode for cathodic protection.

For the purpose of comparing the corrosion resistances of the four metals, the soils were grouped into four environments, as follows: (1) well aerated, acid soils low in soluble salts, 53, 55, 62; (2) poorly aerated soils $(51,56,58,61)$; (3) 
alkaline soils high in soluble salts $(64,65,66,70)$ and (4) soils high in sulfides $(59,60,63)$. In figure 12 , corrosion time curves for soils typical of these environments are shown.

For study of the comparative behavior of copper, lead and zinc in the 14 soils, the average and maximum penetration of each metal were plotted against the duration of exposure (fig. 12). Each point in the curves for copper is the average of a total of eight measurements, made on specimens of four varieties of copper and copper-silicon alloys. For zinc, each point is the average of two measurements made on the specimen of rolled zinc, and for lead, each point is the average of a total of six measurements, made on three varieties of lead. For each soil, corrosion-time curves are also shown to illustrate the average behavior of steel and other wrought ferrous metals that corroded at the same rate as steel in these soils. Each point on these curves is the average of a total of eight measurements made on specimens of carbon steel, mechanically puddled wrought iron, handpuddled wrought iron, and copper molybdenum open-hearth iron. Data on the corrosion of these ferrous materials were given in a previous paper $[2]$.

In all of the soils represented in figure 12 , except Rifle peat (soil 60), the ferrous materials are seen to be corroded at considerably higher rates than any of the other metals. However, because of its poor aeration, high acidity ( $\mathrm{pH} 2.6)$, high content of soluble salts (resistivity $218 \mathrm{ohm}-$ $\mathrm{cm}$ ), and because of the presence of sulfides, none of the materials under consideration with the exception of lead would be expected to withstand for a long period the corrosive action of this soil. Even a heavy zinc coating on steel would probably protect for a short period only because of corrosion of the zine by local action. The inhibitive effect of high concentrations of sulfates on the corrosion of lead, indicated in the curves for soil 60, has been previously referred to.

The curves for soil 64 illustrate the corrosive effect of high concentrations of chlorides on iron, copper, and zinc, and the passifying action of chlorides on lead.

The curves for soils 53 and 56 indicate in a general way the progress of corrosion in well aerated soils low in soluble salts and in poorly aerated soils. With longer periods of exposure, the rates of average and maximum penetration for iron and steel decrease rapidly with time in the well aerated soil (53), but in the poorly aerated soil (56) average and maximum penetration were proportional to the length of exposure. Similarly, the curves for maximum penetration of the other materials show a much greater tendency to decrease with time in the well aerated soil. Under such conditions, ordinary wrought ferrous metals of reasonable thickness would be expected to provide long service.

\section{Summary}

This report contains the results of measurements of corrosion made on specimens of copper, lead, and zinc, and of alloys of these metals exposed to different soil conditions for periods up to $14 \mathrm{yr}$. With respect to weight loss, tough pitch copper was generally more resistant than deoxidized copper and the copper-silicon alloys, except in soils high in sulfides. However, in a number of the soils, the maximum depths of pits on tough-pitch copper were greater than those on one or more of these materials.

The loss in weight of the copper-zinc and coppernickel-zinc alloys was approximately in the order of increasing zinc content, except in soils high in sulfides in which the reverse order was followed. Admiralty metal $(70 \%$ of $\mathrm{Cu}, 29 \%$ of $\mathrm{Zn}, 1 \%$ of $\mathrm{Sn})$ showed the greatest tendency toward localized corrosion of any of the copper-zinc alloys. Although a two-phase leaded silicon brass $(67 \%$ of $\mathrm{Cu}, 31 \%$ of $\mathrm{Zn}, 1 \%$ of $\mathrm{Si}$, and $0.8 \%$ of $\mathrm{Pb}$ ) showed the least tendency to develop deep pits, this alloy was dezincified in many of the soils. All twophase copper-zinc alloys were dezincified to some extent in most of the soils, except a $60-40$ brass containing 0.08 percent of arsenic, which showed only superficial discoloration. The presence of arsenic did, however, induce intergranular corrosion in the specimens exposed to cinders.

No differences were observed in the corrosion of chemical lead, antimonial lead, and tellurium lead.

A die-casting zinc alloy had greater maximum pit depths than rolled zinc, but there was no significant difference in weight loss.

In general, copper, zinc, and lead, and alloys of these metals were corroded most severely in poorly aerated soils, particularly, in soils that were highly acid or that contained high concentrations of soluble salts. Copper was corroded in soils high 
in sulfides. Lead was passivated by soils containing high concentrations of sulfa tes and chlorides.

The field tests in this paper were initiated and installed, and until 1946 were conducted, under the supervision of K. H. Logan. The measurements of corrosion were made chiefly by Warren P. Dettmers, who also assisted in other capacities.

\section{References}

[1] K. H. Logan, NBS Circular C450, Underground corrosion (1945).

[2] I. A. Denison and M. Romanoff, J. Research NBS 44, 47 (1950) RP2057.
[3] D. K. Crampton, Ind. Eng. Chem. 28, 1397 (1936).

[4] G. O. Hiers, Corrosion handbook (John Wiley and Sons, New York, N. Y., 1948).

[5] P. D. Merica, Chem. Met. Eng. 16, 657 (1917).

[6] A. W. Tracy, Heating, Piping, Air Conditioning 14, 538 (1942).

[7] K. H. Logan, S. P. Ewing, and I. A. Denison, Symposium on corrosion testing procedures, ASTM (Philadelphia, Pa., 1937).

[8] L. M. Martin, NBS Soil corrosion conference, unpublished (1937).

[9] Mordecai Ezekiel, Methods of correlation anaiysis (John Wiley and Sons, Inc., New York, N. Y., 1930).

[10] R. M. Burns, Bell Syst. Tech. J. 15, 603 (1936). 

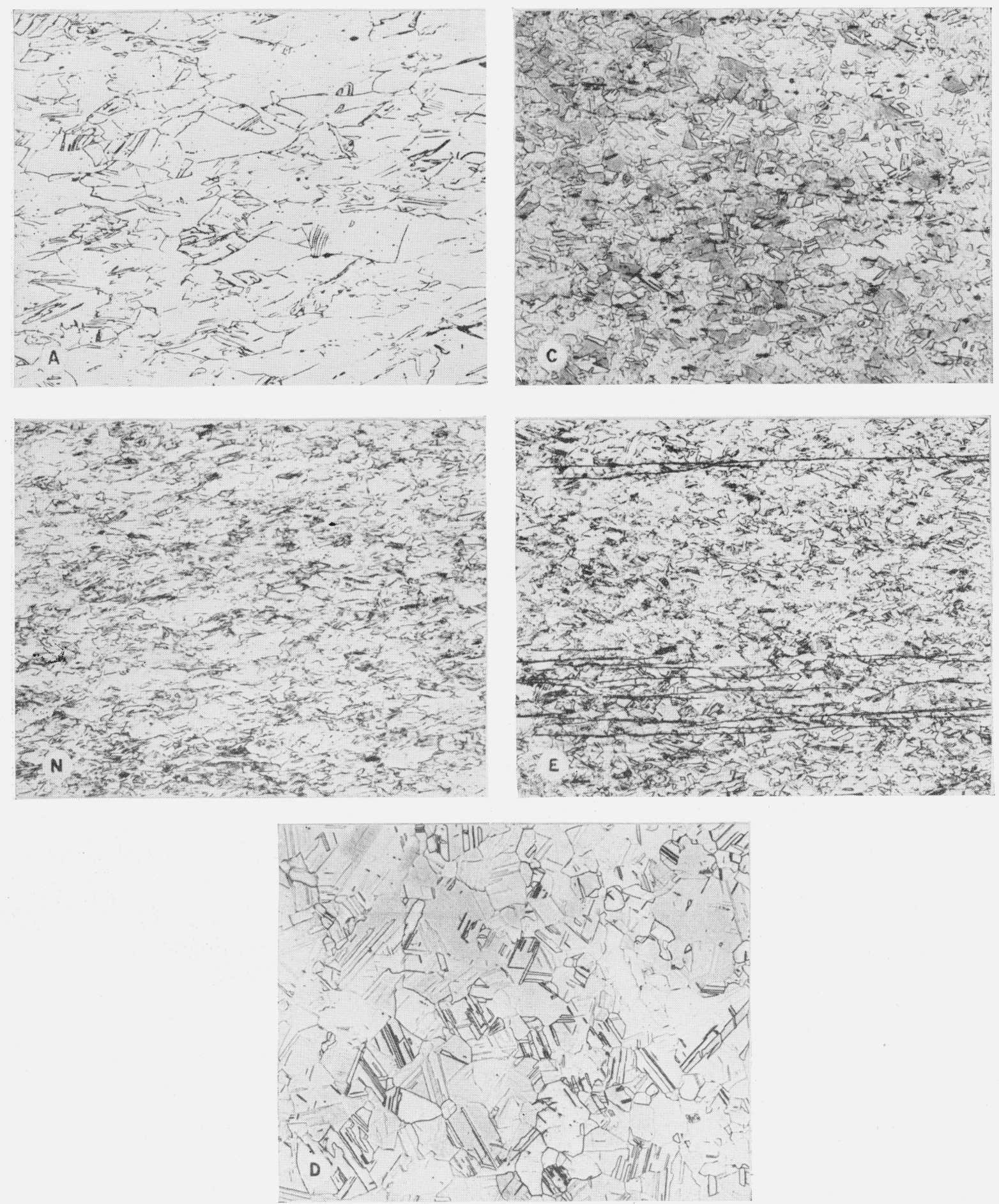

FiguRE 1. Structures of specimens of copper and copper-silicon alloys, $\times 100$.

A, Deoxidized copper; C, tough-pitch copper; N, copper-silicon alloy; E, copper-silicon alloy; D, copper-silicon alloy. See table 2 for composition of materials. Etching solutions: $\mathrm{A}, \mathrm{FeCl}_{3}$ and swabbed with $\mathrm{CrO}_{3} ; \mathrm{C},\left(\mathrm{NH}_{4}\right)_{2} \mathrm{~S}_{2} \mathrm{O}_{8} ; \mathrm{N}, \mathrm{E}$, and $\mathrm{D}, \mathrm{K}_{2} \mathrm{Cr}_{2} \mathrm{O}_{7}+\mathrm{FeCl}_{3}$. 

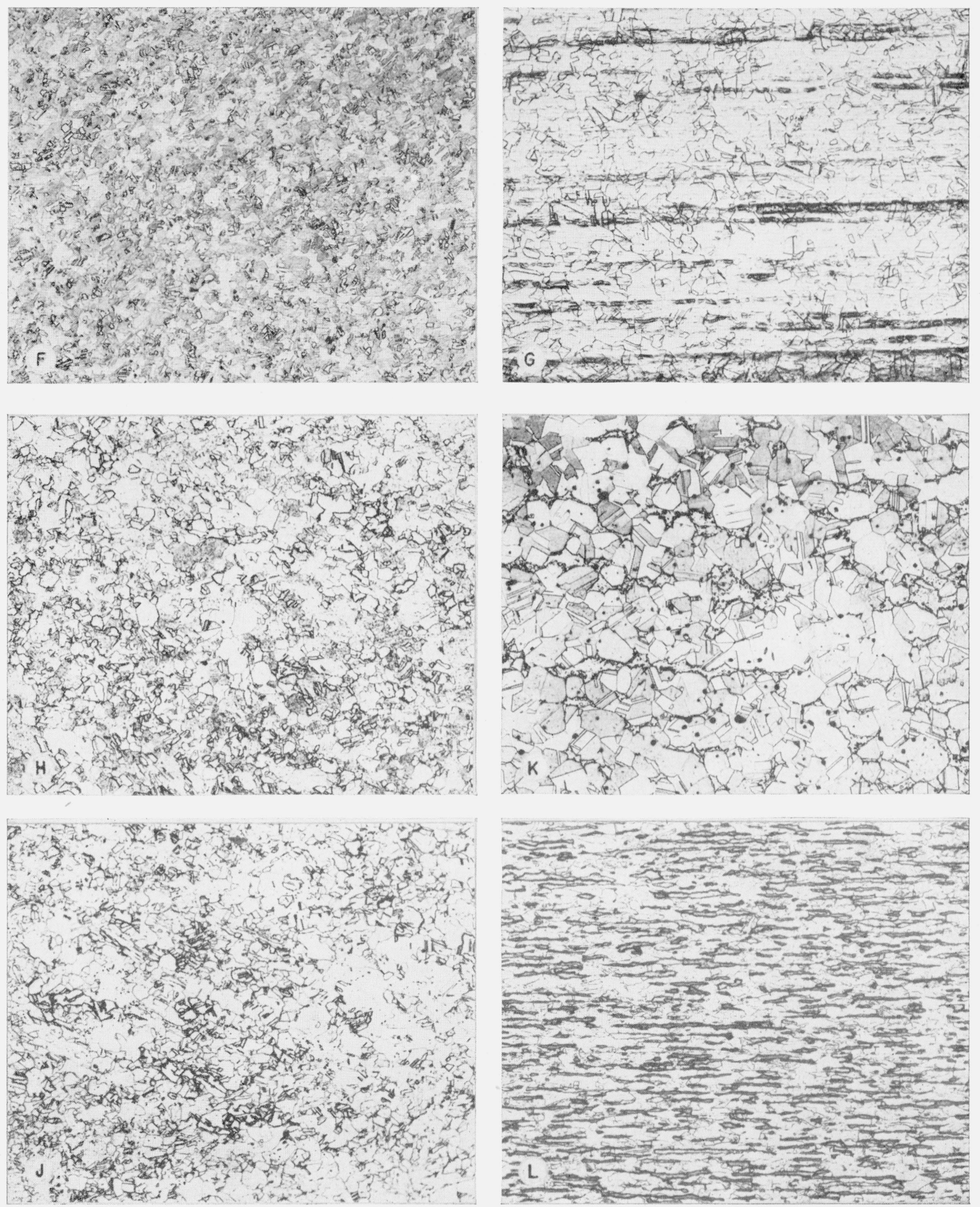

FIGURE 2. Structures of specimens of copper-zinc alloys and copper-nickel-zinc alloy, $\times 100$.

T F, Red brass; G, copper-nickel-zine alloy; H, Admiralty metal; K, leaded-silicon brass; J, yellow brass; L, Muntz metal. See table 2 for composition of materials. Etching solutions: F, $\left(\mathrm{NH}_{4}\right)_{2} \mathrm{~S}_{2} \mathrm{O}$; $\mathrm{G}, \mathrm{H}, \mathrm{K}$, and $\mathrm{J}, \mathrm{K}_{2} \mathrm{Cr}_{2} \mathrm{O}_{7}+\mathrm{FeCl}_{3} ; \mathrm{L}, \mathrm{FeCl}_{3}+\mathrm{K}_{2} \mathrm{Cr}_{2} \mathrm{O}_{7}+\mathrm{Cr}_{2} \mathrm{O}_{3}$. 


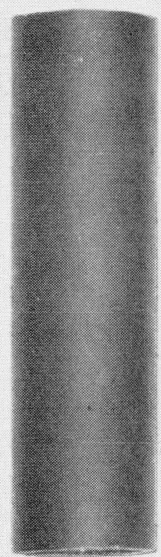

51

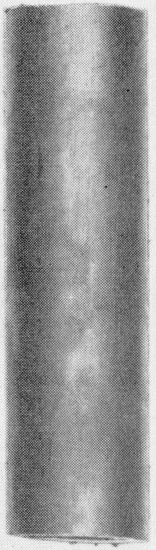

59

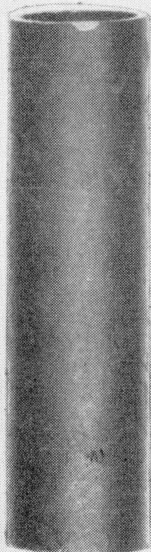

64

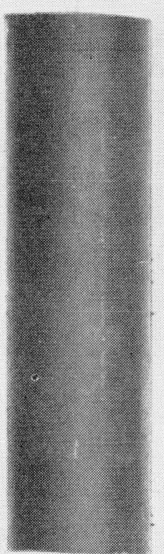

53

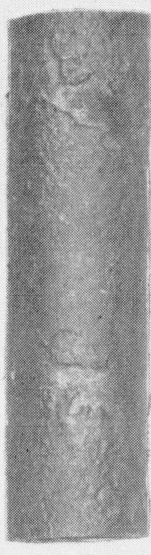

60

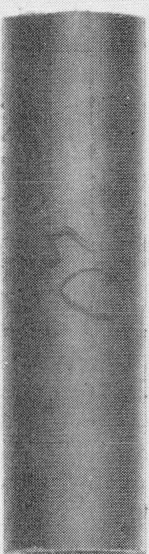

55

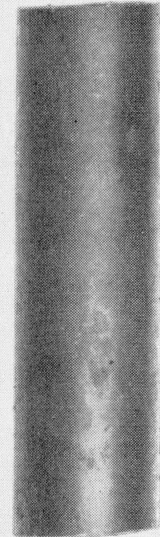

61

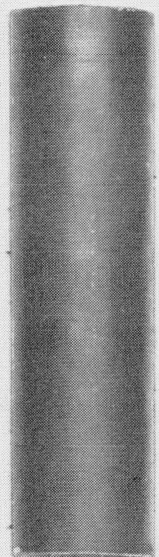

56

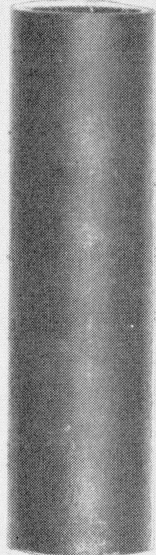

62

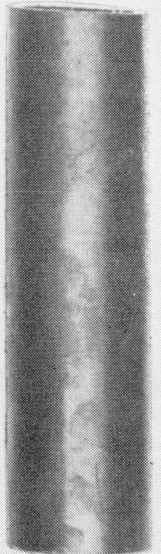

66

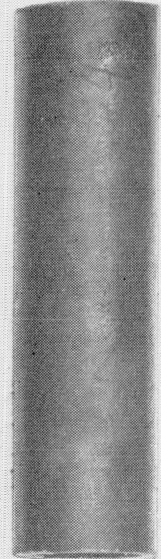

58

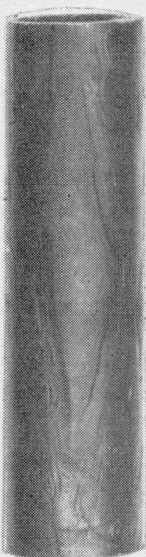

63

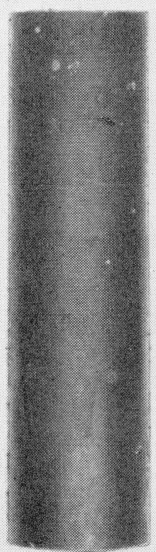

65

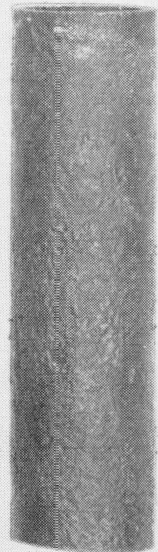

67

FIGURE 3. Condition of specimens of tough pitch copper removed after exposure for 14 years to 14 soils. 
ACID SOILS
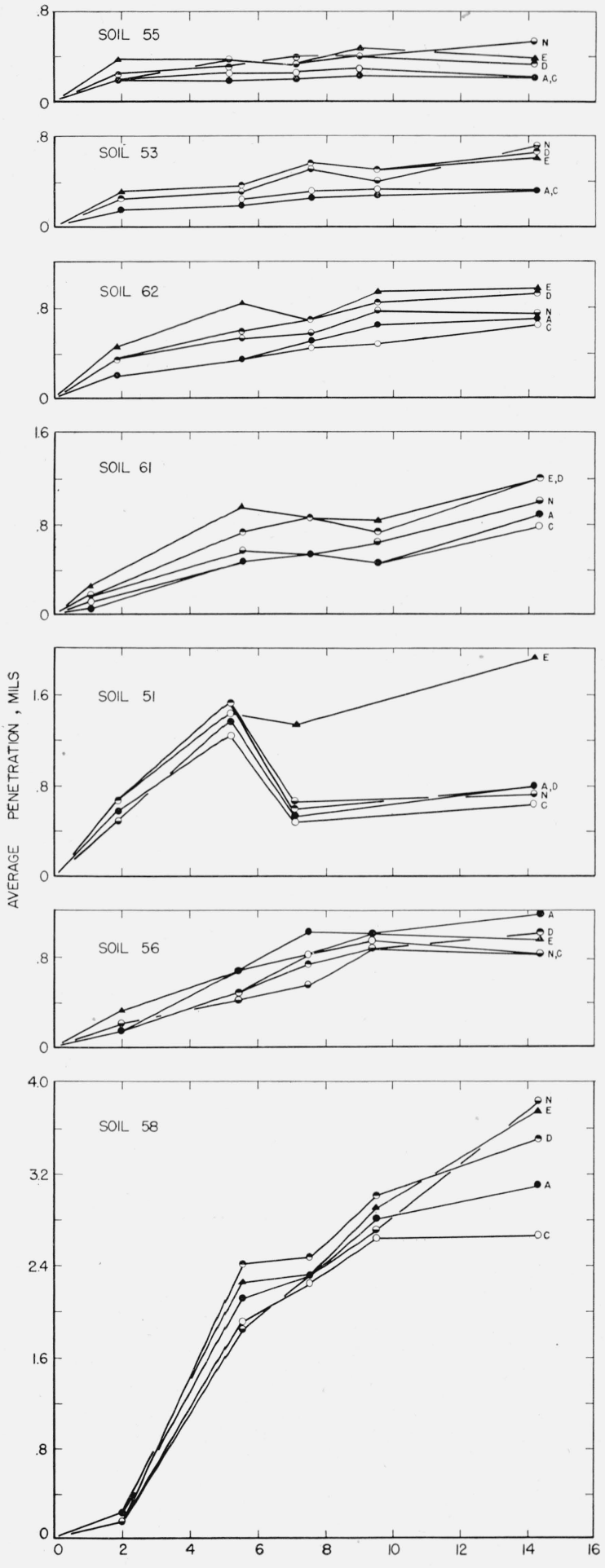

TIME, YEARS
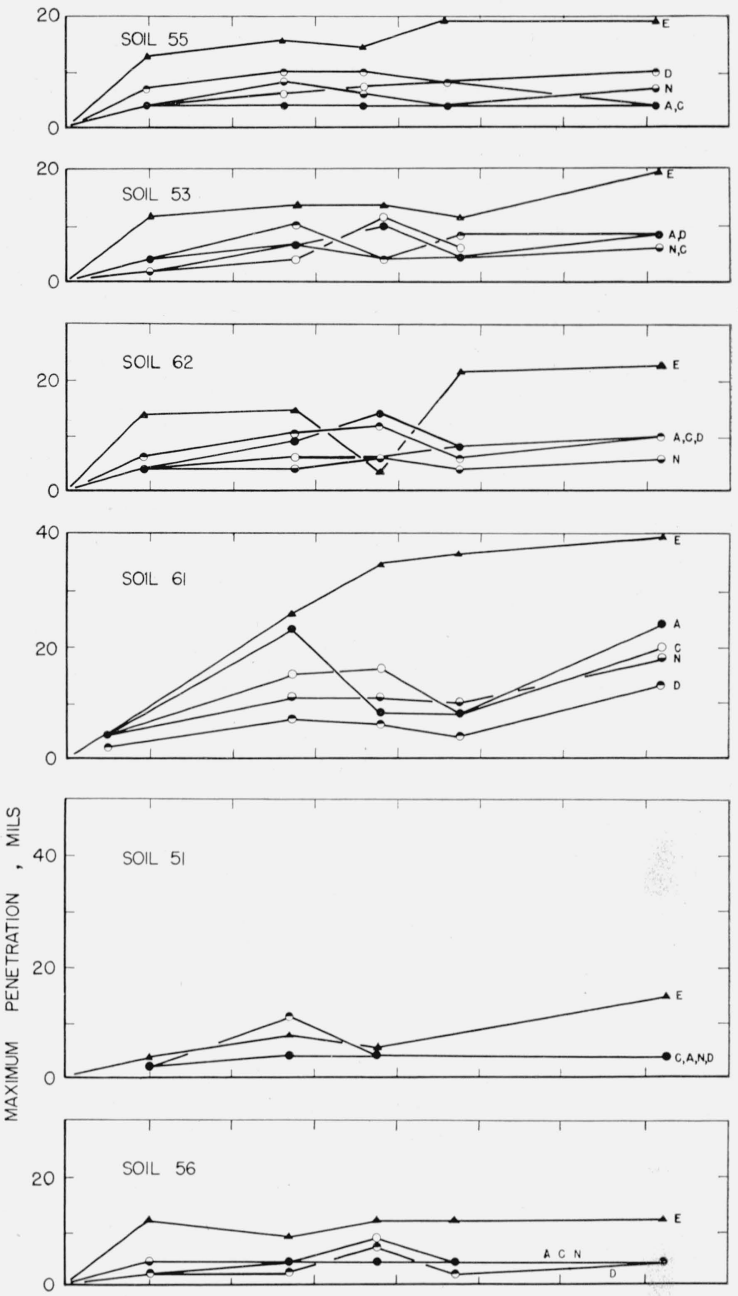

FiguRE 4. Average and maximum penetration-time curves of copper and copper-silicon alloys.

Each point is the average of 2 specimens. O, C, tough-pitch copper, $99.9 \% \mathrm{Cu}$. $\bullet$, A, deoxidized copper, $99.94 \% \mathrm{Cu}, 0.018 \% \mathrm{P} . \boldsymbol{\Theta}, \mathrm{D}$, copper-silicon alloy, $95.46 \% \mathrm{Cu}, 3.19 \% \mathrm{Si} . \quad \odot, \mathrm{N}$, copper-silicon alloy, $98.11 \% \mathrm{Cu}, 1.49 \% \mathrm{Si} . \quad \mathbf{\Lambda}, \mathrm{E}$, bronze, $97.15 \% \mathrm{Cu}, 1.04 \% \mathrm{Si}, 1.80 \% \mathrm{Sn}$. 

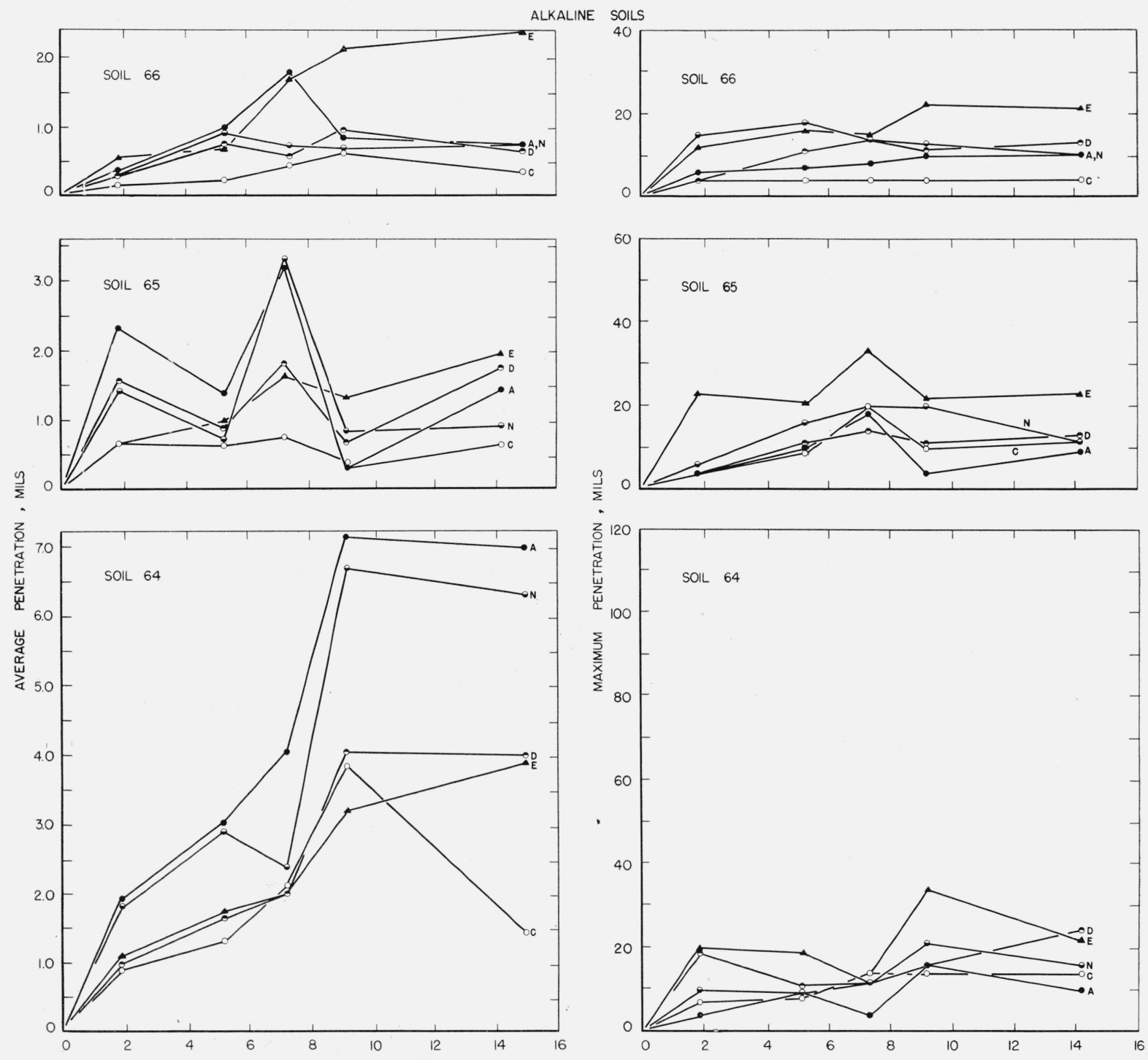

FIgURE 4-Continued. Average and maximum penetration-time curves of copper and copper-silicon alloys.

Each point is the average of 2 specimens. $\bigcirc$, C, tough-pitch copper, $99.9 \% \mathrm{Cu}$., $\mathrm{A}$, deoxidized copper, $99.94 \% \mathrm{Cu}, 0.018 \% \mathrm{P} . \bullet, \mathrm{D}$, copper-silicon alloy $95.46 \% \mathrm{Cu}, 3.19 \% \mathrm{Si} . \quad \odot, \mathrm{N}$, copper-silicon alloy, $98.11 \% \mathrm{Cu}, 1.49 \% \mathrm{Si}$. $\mathbf{\Lambda}, \mathrm{E}$, bronze, $97.15 \% \mathrm{Cu}, 1.04 \% \mathrm{Si}, 1.80 \% \mathrm{Sn}$. 

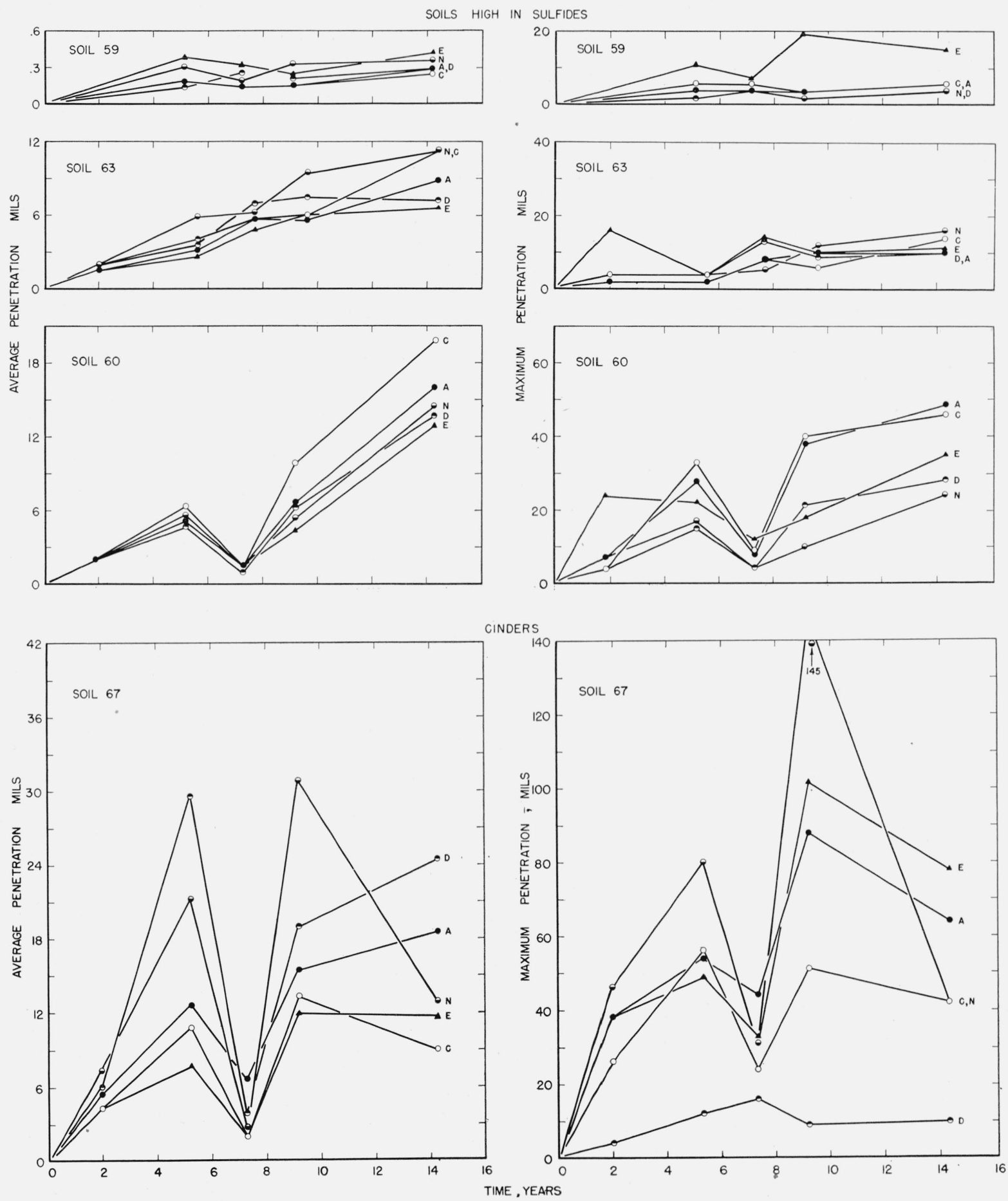

Figure 4-Continued. Average and maximum penetration-time curves of copper and copper-silicon alloys.

Each point is the average of 2 specimens. $\mathrm{O}$, C, tough-pitch copper, $99.9 \% \mathrm{Cu}$. $\bullet$, A, deoxidized copper, $99.94 \% \mathrm{Cu}, 0.018 \%$ P. $\bullet$, D, copper-silicon alloy, $95.46 \% \mathrm{Cu}, 3.19 \% \mathrm{Si} . \quad \ominus, \mathrm{N}$, copper-silicon alloy, $98.11 \% \mathrm{Cu}, 1.49 \% \mathrm{Si}$

$\mathbf{\Lambda}, \mathrm{E}$, bronze, $97.15 \% \mathrm{Cu}, 1.04 \% \mathrm{Si}, 1.80 \% \mathrm{Sn}$. 
ACID SOILS
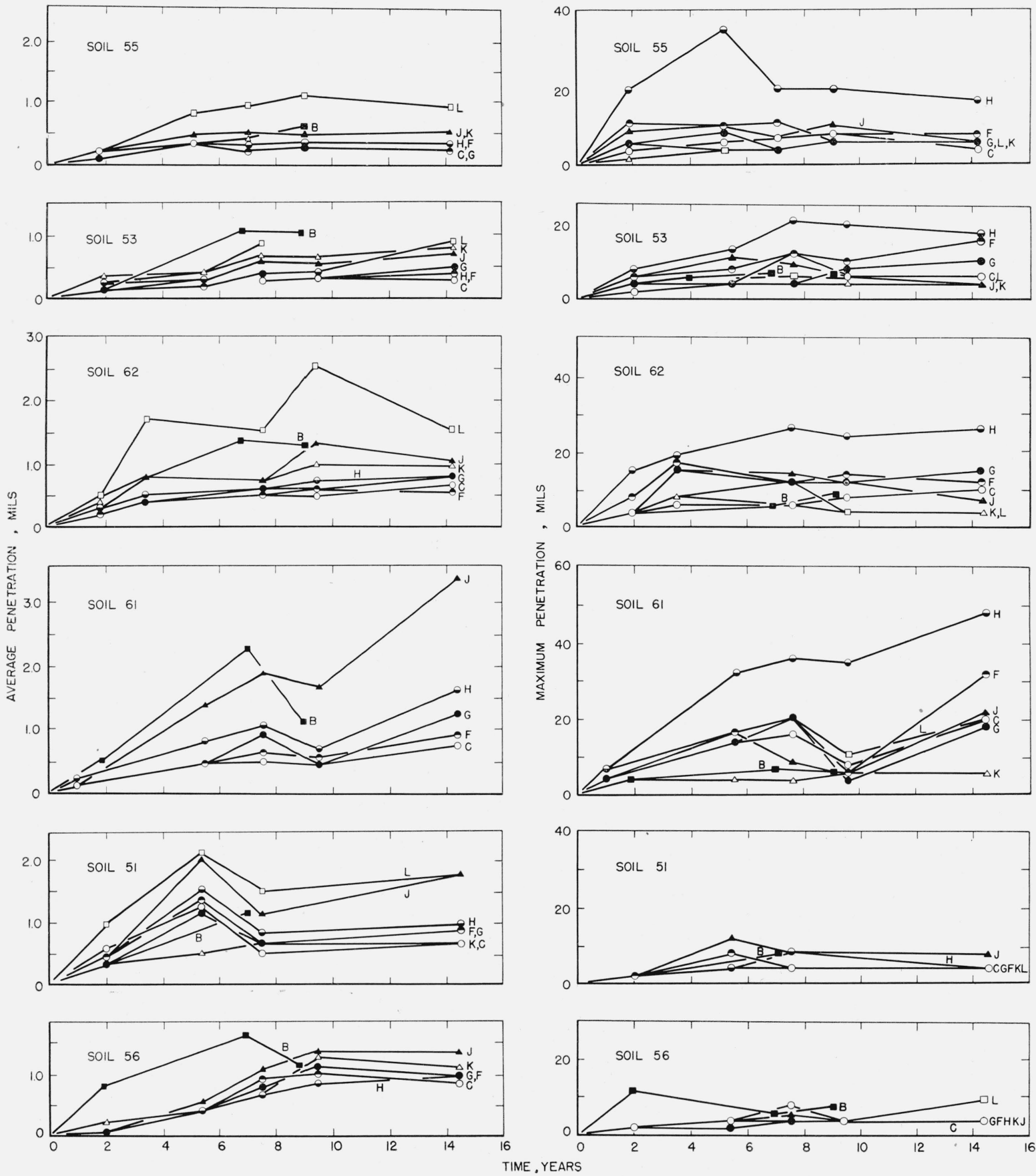

FIGURE 5. Average and maximum penetration-time curves of copper-zinc alloys and copper-nickel-zinc.

Each point is the average of 2 specimens. The average penetration-time curves for the specimens whose weight loss was appreciably affected by dezincifi-

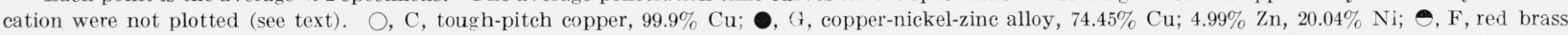
$85.18 \% \mathrm{Cu}, 14.80 \% \mathrm{Zn}: \bullet$ H, Admiralty met: $1,71.28 \% \mathrm{Cu}, 27.39 \% \mathrm{Zn}, 1.30 \% \mathrm{Sn}, 0.01 \% \mathrm{~Pb} ; \triangle$, K, leaded-silicon brass, $67.08 \% \mathrm{Cu}, 31.07 \% \mathrm{Zn}, 0.84 \% \mathrm{~Pb} ; \boldsymbol{\Delta}$ J, yellow brass, $66.50 \% \mathrm{Cu}, 33.06 \% \mathrm{Zn}, 0.42 \% \mathrm{~Pb}$; $\square$, L, Muntz metal, $62.37 \% \mathrm{Cu}, 37.51 \% \mathrm{Zn}, 0.36 \% \mathrm{~Pb}$; 圈, B, Muntz metal with arsenic, $62.37 \% \mathrm{Cu}, 37.54 \%$ $\mathrm{Zn}, 0.005 \% \mathrm{~Pb}, 0.08 \% \mathrm{As}$ 
ACID SOILS
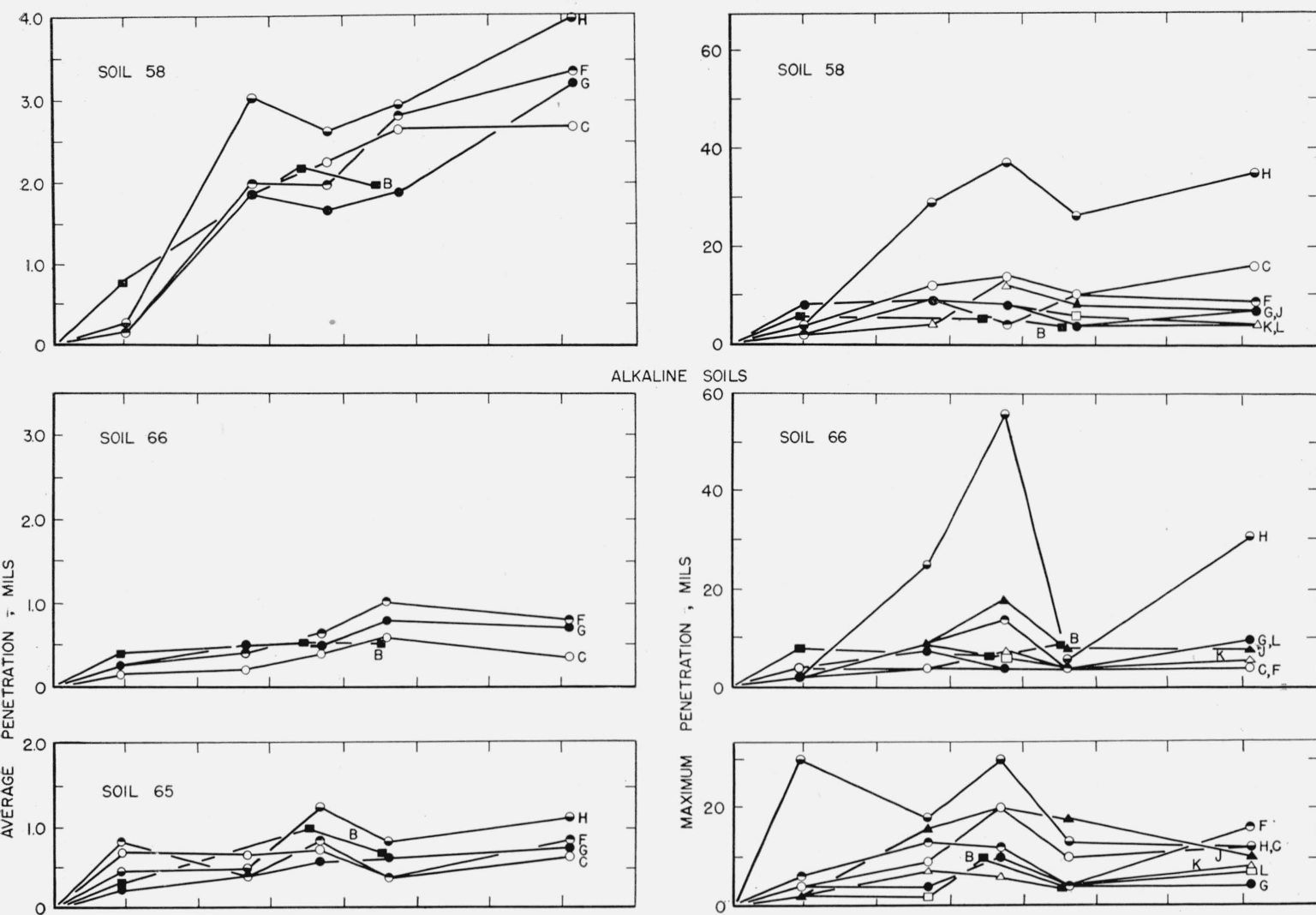

ALKALINE SOILS
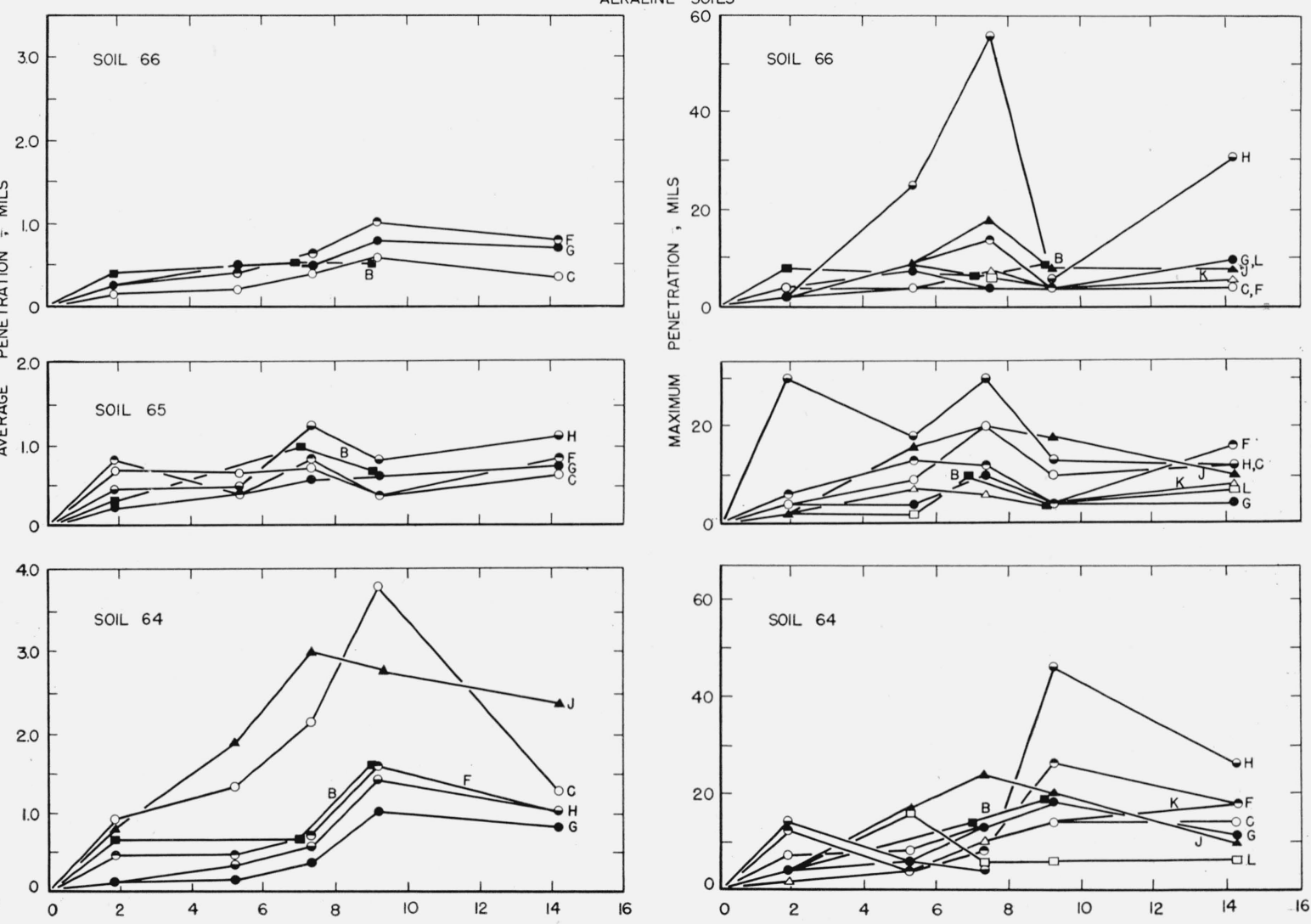

FIGURE 5-Continued. Average and maximum penetration-time curves of copper-zinc alloys and copper-nickel-zinc.

Each point is the average of 2 specimens. The average penetration-time curves for the specimens whose weight loss was appreciably affected by dezincification were not plotted (see text). O, C, tough-pitch copper, $99.9 \% \mathrm{Cu} ; \boldsymbol{\bullet}, \mathrm{G}$, copper-nickel-zinc alloy, $74.45 \% \mathrm{Cu} ; 4.99 \% \mathrm{Zn}, 20.04 \% \mathrm{Ni} ; \boldsymbol{\bullet}, \mathrm{F}, \mathrm{red}$ brass $85.18 \% \mathrm{Cu}, 14.80 \% \mathrm{Zn} ; \bullet, \mathrm{H}$, Admiralty metal, $71.28 \% \mathrm{Cu}, 27.39 \% \mathrm{Zn}, 1.30 \% \mathrm{Sn}, 0.01 \% \mathrm{~Pb} ; \triangle$, K, leaded-silicon brass, $67.08 \% \mathrm{Cu}, 31.07 \% \mathrm{Zn}, 0.84 \% \mathrm{~Pb} ; \mathbf{\Lambda}, \mathrm{J}$, yellow brass, $66.50 \% \mathrm{Cu}, 33.06 \% \mathrm{Zn}, 0.42 \% \mathrm{~Pb}$; $\square$, L, Muntz metal, $62.37 \% \mathrm{Cu}, 37.54 \% \mathrm{Zn}, 0.36 \% \mathrm{~Pb}$; $\mathbf{\square}$, B, Muntz metal with arsenic, $62.37 \% \mathrm{Cu}, 37.54 \% \mathrm{Zn}$, $0.005 \% \mathrm{~Pb}, 0.08 \% \mathrm{As}$. 

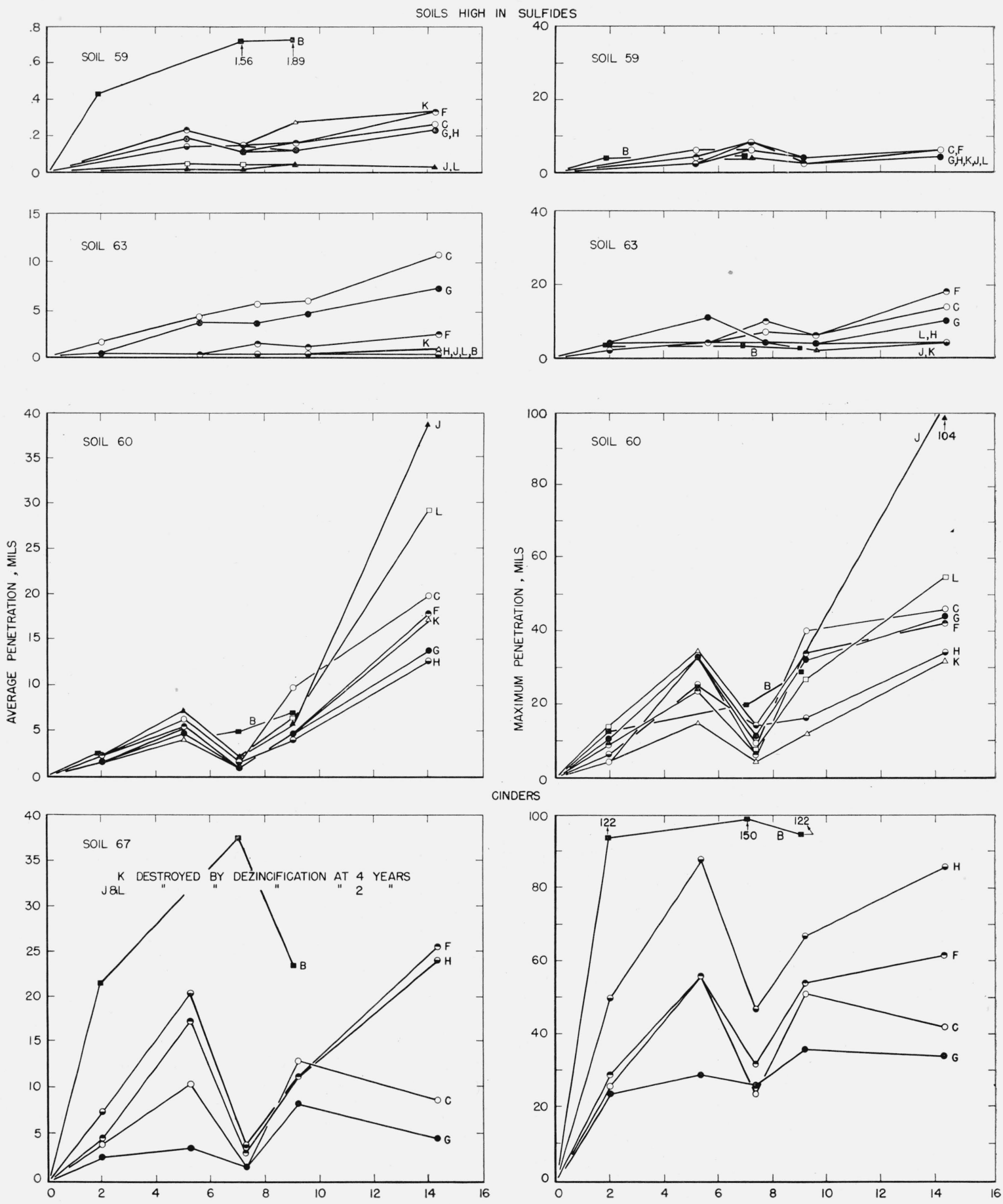

CINDERS

TIME, YEARS

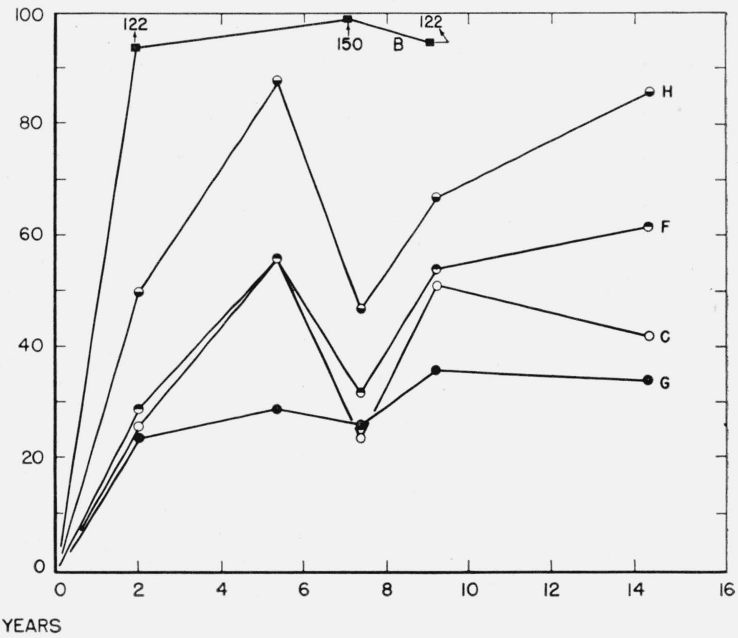

FiguRE 5-Continued. Average and maximum penetration-time curves of copper-zinc alloys and copper-nickel-zinc.

Each point is the average of 2 specimens. The average penetration-time curves for the specimens whose weight loss was appreciably affected by dezincification were not plotted (see text). O, C, tcugh-pitch e spper, $99.9 \% \mathrm{Cu}$ - G, espper-nickel-zinc alloy, $74.45 \% \mathrm{Cu}, 4.99 \% \mathrm{Zn}, 20.04 \% \mathrm{Ni} ; \boldsymbol{\ominus}, \mathrm{F}$. red brass $85.18 \% \mathrm{Cu}, 14.80 \% \mathrm{Zn} ; \boldsymbol{\odot}, \mathrm{H}$, Admiralty metal, $71.28 \% \mathrm{Cu}, 27.39 \% \mathrm{Zn}, 1.30 \% \mathrm{Sn}, 0.01 \% \mathrm{~Pb} ; \triangle$, K, leaded-silicon brass, $67.08 \% \mathrm{Cu}, 31.07 \% \mathrm{Zn}, 0.84 \% \mathrm{~Pb} ; \mathbf{\Delta}, \mathrm{J}$, yellow brass, $66.50 \% \mathrm{Cu}, 33.06 \% \mathrm{Zn}, 0.42 \% \mathrm{~Pb} ; \square$, L, Muntz metal, $62.37 \% \mathrm{Cu}, 37.54 \% \mathrm{Zn}, 0.36 \% \mathrm{~Pb}$; $\mathbf{\text { r }}$, B, Muntz metal with arsenic, $62.37 \% \mathrm{Cu}, 37.54 \% \mathrm{Zn}$, $0.005 \% \mathrm{~Pb}, 0.08 \% \mathrm{As}$. 


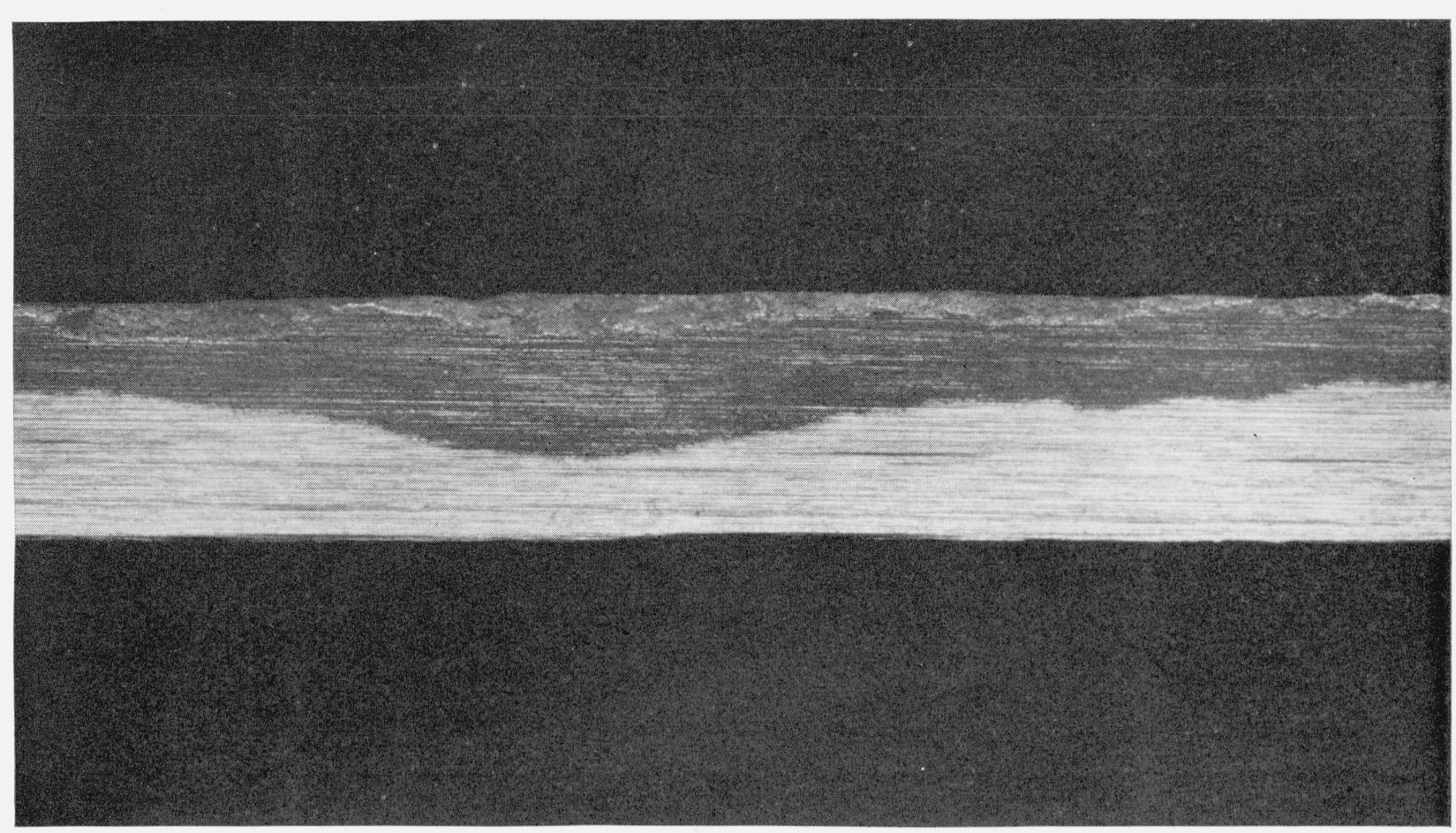

Figure 6. Dezincification of Muntz metal exposed 14 years to Sharkey clay. Transverse section showing transition from uncorroded metal to the uniformly dezincified layer, $\times 15$.

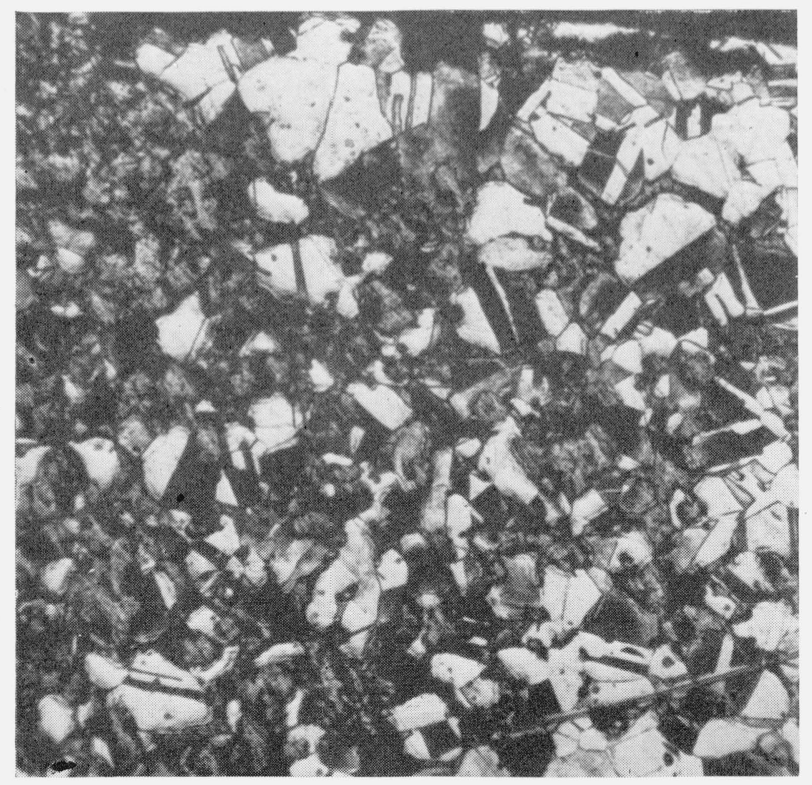

Figure 7. Leaded silicon brass $(K)$ exposed 9.5 years to Sharkey clay (soil 61).

Transverse section showing partial dezincification. The dezincification is more severe at the left, as indicated by the dark, spongy-like areas with irregular boundaries. Light grains of the alpha phase in dezincified areas show that the grains of the beta phase are dezincified first, $\times 250$.

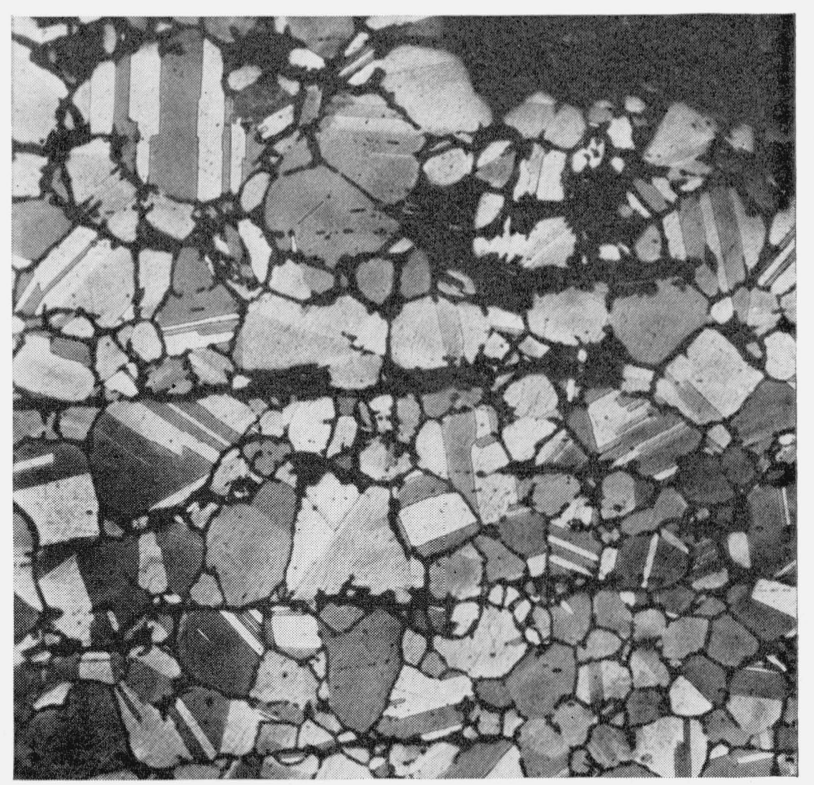

Figure 8. Microstructure of Muntz metal containing $0.08 \%$ arsenic.

Transverse section of specimen exposed 7 years to cinders (site 67) showing intergranular corrosion, $\times 109$. 


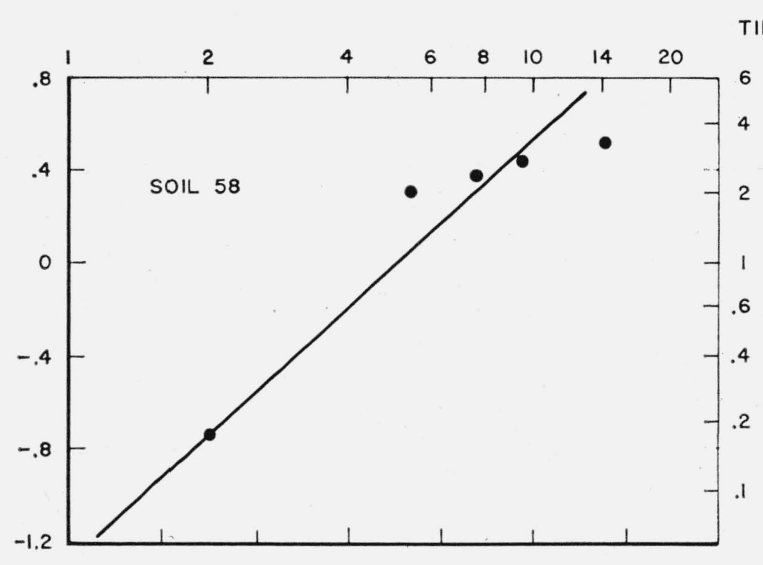

TIME, YEARS
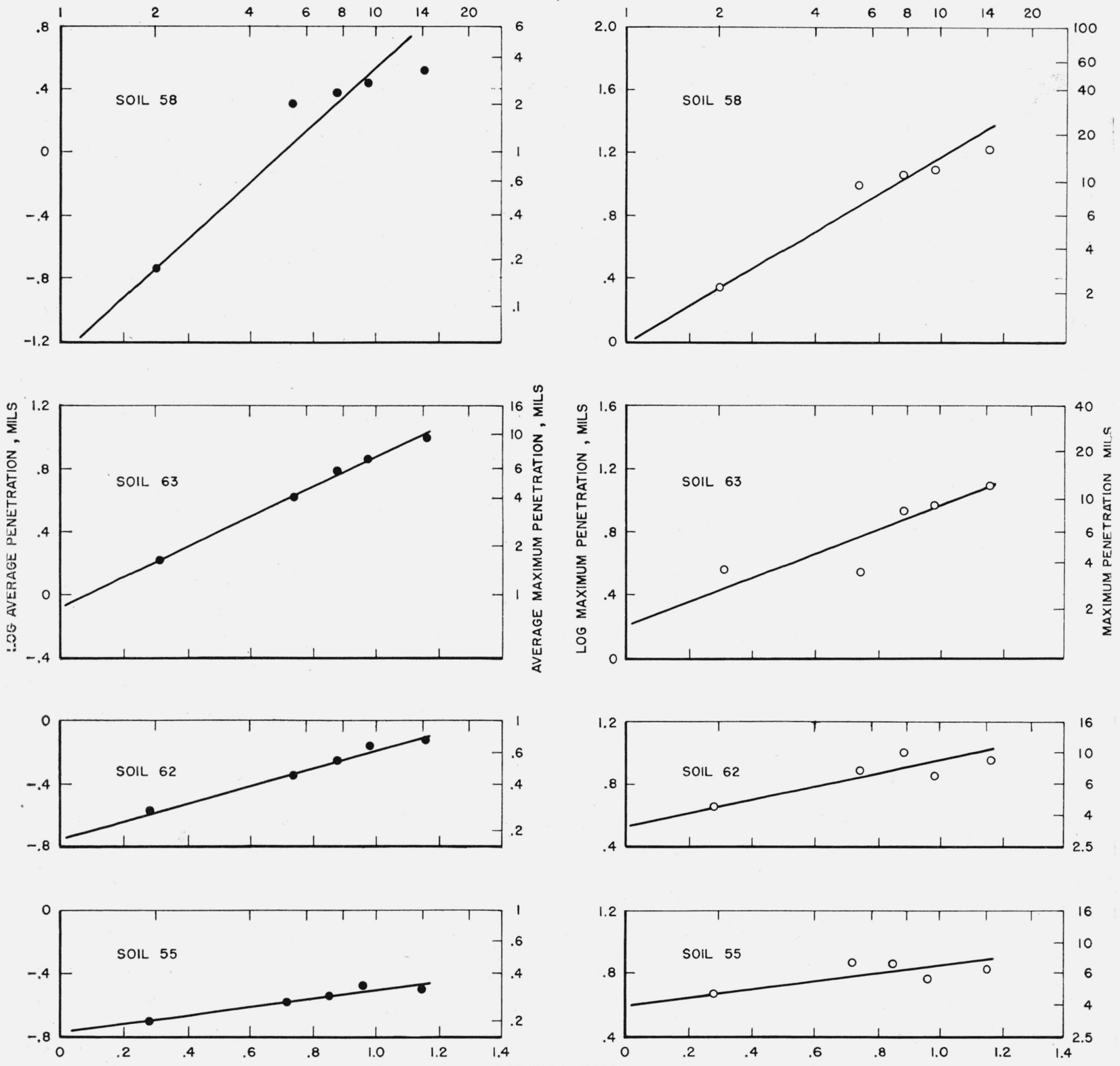

FIGURE 9. Average and maximum penetration-time curves of copper in typical soils on logarithmic coordinates.

-, Log average penetration; $\bigcirc, \log$ maximum penetration. 


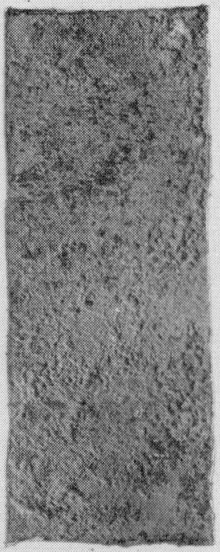

$5 !$

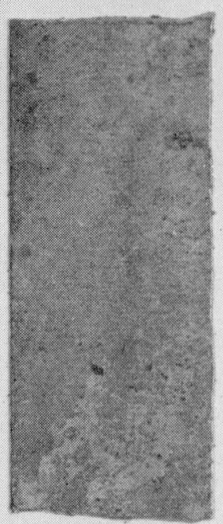

59

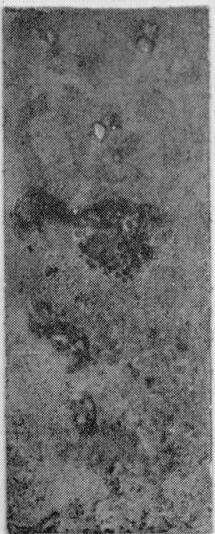

64

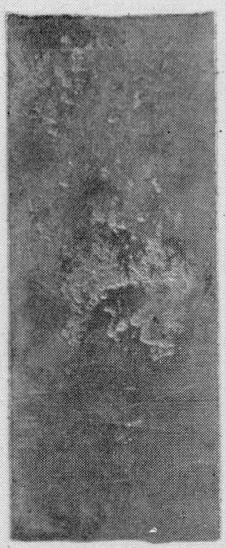

53

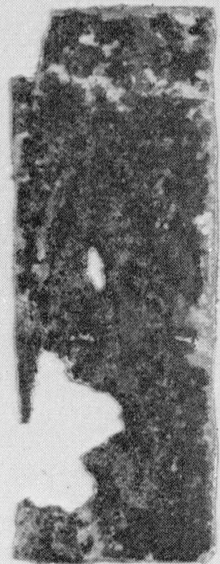

60

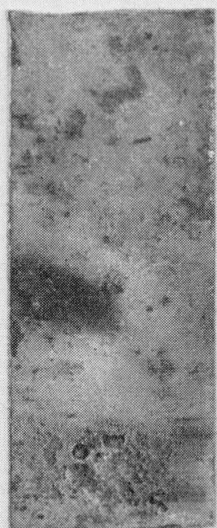

65

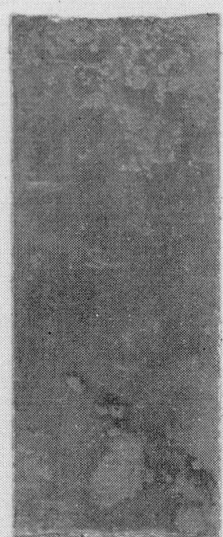

55

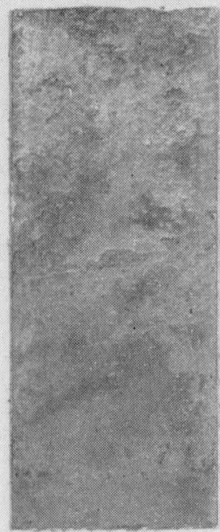

61

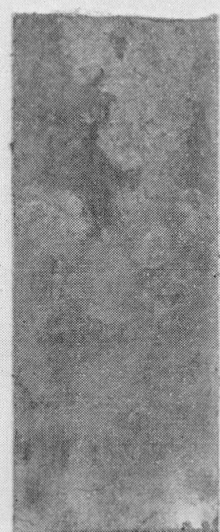

66

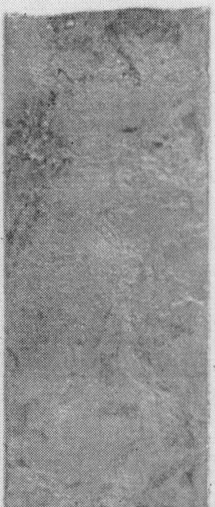

56

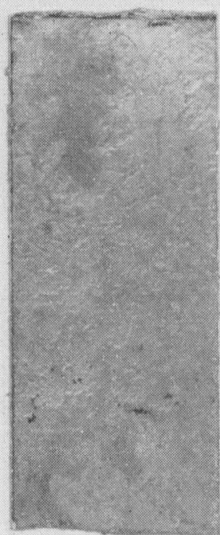

62

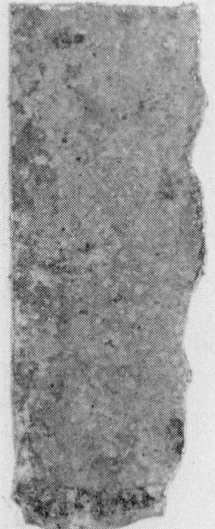

67

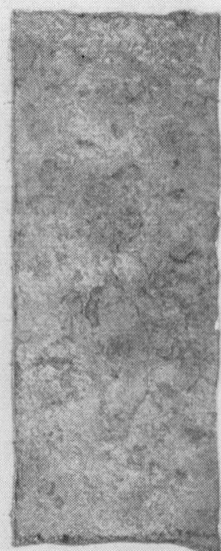

58

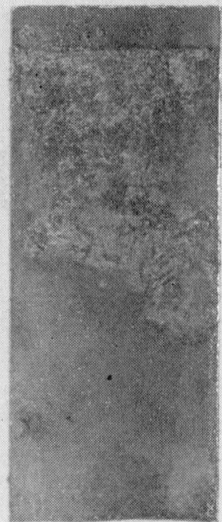

63

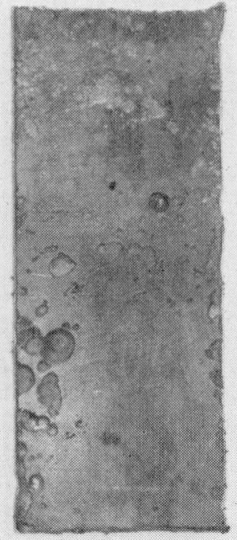

70

FIguRE 10. Condition of specimens of rolled zinc $(Z)$ exposed 9 years to 15 soils 


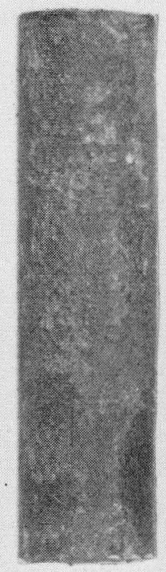

51

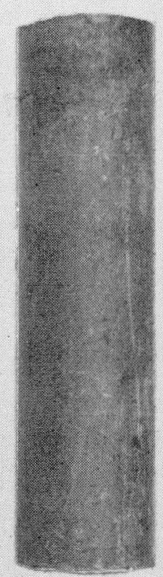

59

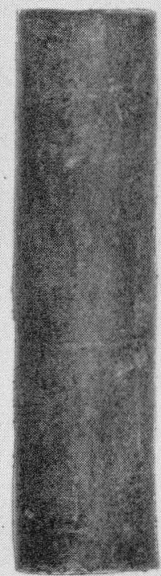

64

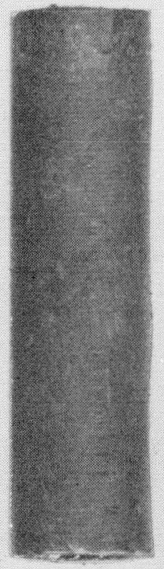

53

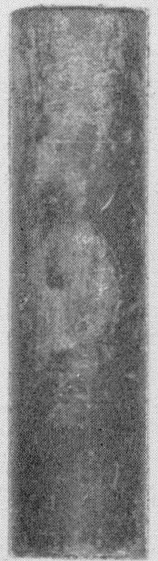

60

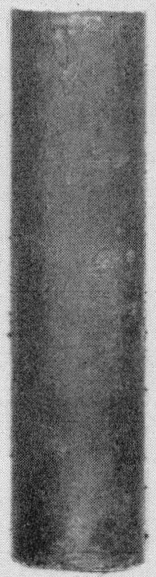

65

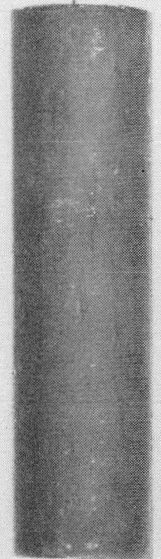

55

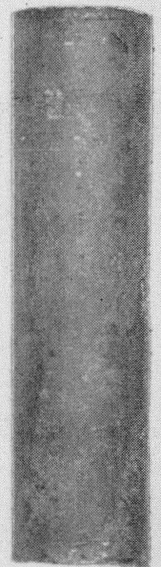

61

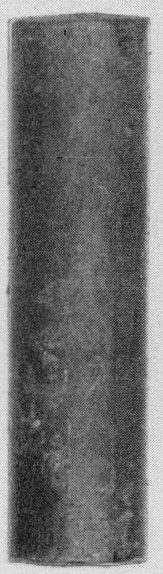

66

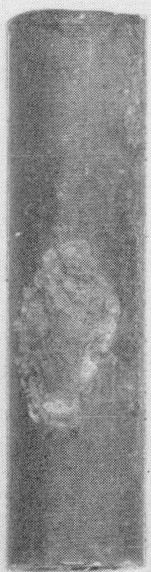

56

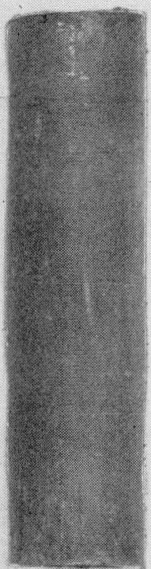

62

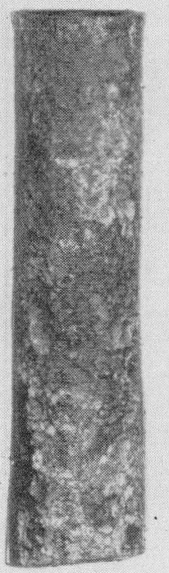

67

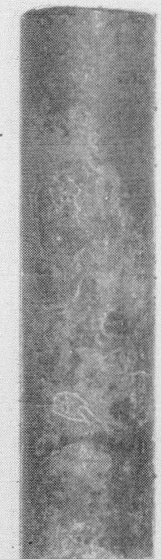

58

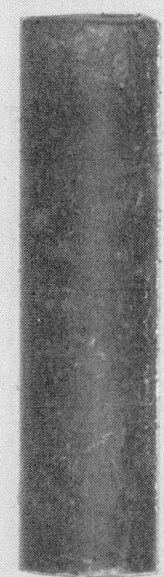

63

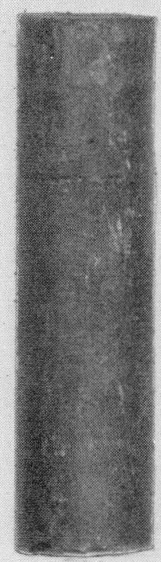

70

Figure 11. Condition of chemical lead $(O)$ exposed 9 years to 15 soils. 

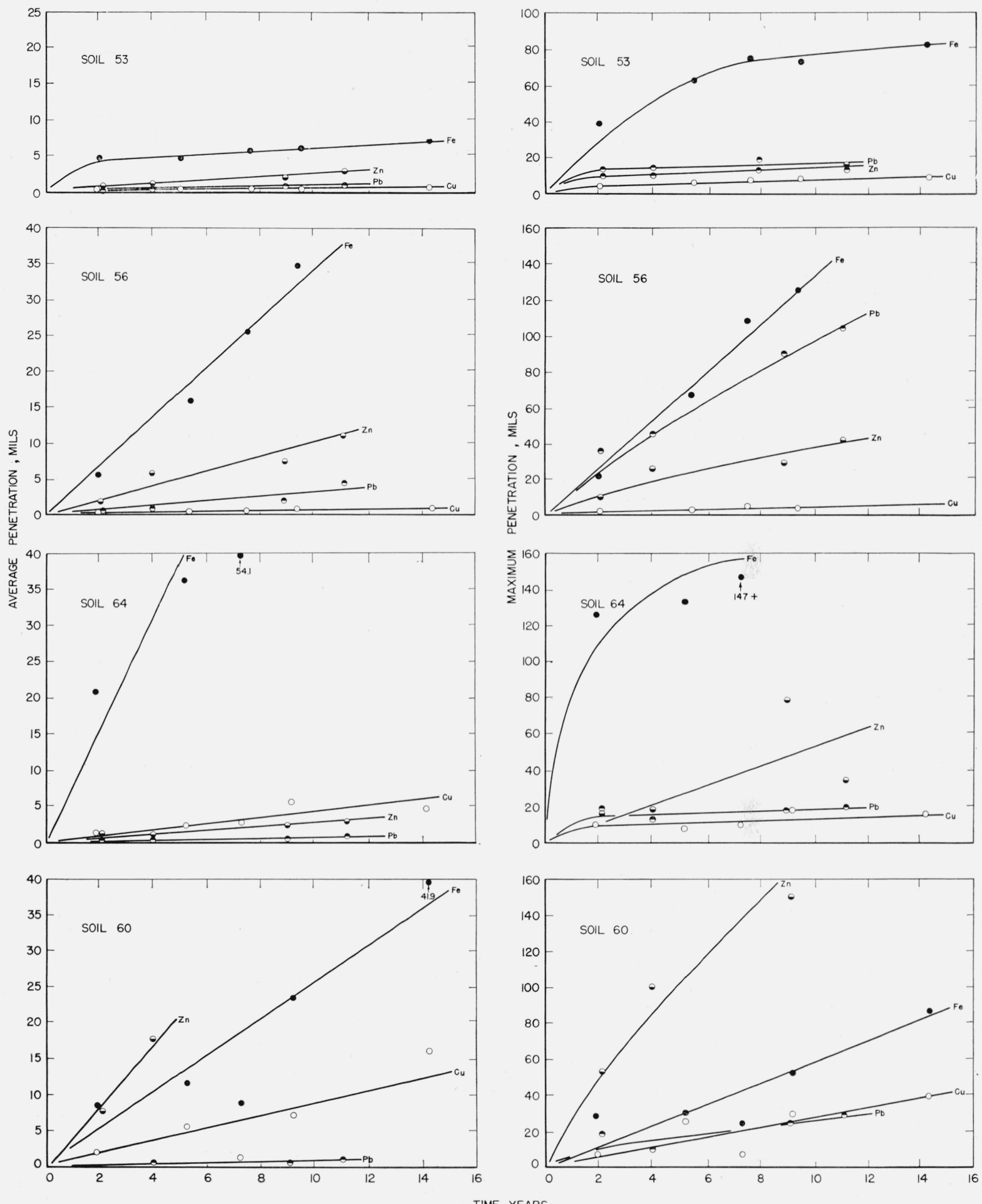

FIGURE 12. Average and maximum penetration-time curves of steel, copper, lead, and zinc in representative soil environments.

$\bullet$, Steel; $\bigcirc$, copper; $\bullet$, lead; $\bullet$, zinc.

Washington, October 7, 1949. 